\title{
SIEĆ OSADNICZA I SZLAKI KOMUNIKACYJNE NA ZACHÓD OD POZNAŃSKIEGO PRZELOMU WARTY W STARSZYCH FAZACH WCZESNEGO ŚREDNIOWIECZA
}

\author{
A SETTLEMENT NETWORK AND TRANSPORT ROUTES TO THE WEST \\ OF THE POZNAŃ WARTA GORGE IN THE OLDER STAGES \\ OF THE EARLY MIDDLE AGES
}

\begin{abstract}
In the oldest stages of the early Middle Ages, the settlements located between the Warta and the Obra were concentrated predominantly in a few areas: between the Warta, the Sama and the Samica Stęszewska, in the vicinity of Pniewy and Lwówek, and to the west of Sieraków. The resulting structure, over time supplemented with settlement clusters in Opalenica Plain, formed the basis for a network of gords established in the $9^{\text {th }}$ and the early $10^{\text {th }}$ centuries. The arrangement of hamlets and gords allowed to reconstruct long-range transport routes connecting these regions with south Wielkopolska, Lusatia as well as the north-western Slavic domains.
\end{abstract}

Keywords: early Middle Ages, waterways, inland routes, settlement network, tribal gords, spurs.

Kluczową kwestią dla rozwoju społeczeństw, począwszy od pradziejów po czasy współczesne, pozostaje komunikacja, którą rozumiemy zarówno jako sposób przekazywania tradycji werbalnej i pozawerbalnej, jak i ,fizyczne” przemieszczanie się pojedynczych osób i całych społeczności. Oba te rodzaje komunikacji są ze sobą nierozerwalnie związane, trudno bowiem wyobrazić sobie przekazywanie wiedzy, umiejętności, czy też konkretnych wytworów kultury bez pokonania w przestrzeni drogi, która umożliwia spotkanie i przekaz. Część szlaków, omijając pasma górskie, bagna czy tereny, które skutecznie utrudniały podróż, w ciągu tysiącleci pozostawała niezmieniona i łączyła bliższe i dalsze siedziby ludzkie. Choć wiedzę o dokładnym przebiegu dawnych traktów czerpiemy z przekazów pisanych lub zachowanej kartografii, to ich przybliżony przebieg możemy rekonstruować także

* ORCID: 0000-0003-4462-3763, Muzeum Pierwszych Piastów na Lednicy, Dziekanowice 23, 62-261 Lednogóra, ewa.pawlak@lednica.pl. 
dla wcześniejszych, przedpiśmiennych czasów właśnie na podstawie pozostałości osadnictwa.

We wszystkich analizach dotyczących sieci komunikacyjnej podkreślana jest ogromna rola dolin wielkich rzek, wzdłuż których po dziś dzień skupiają się stolice i najważniejsze ośrodki współczesnego świata. Rzeki zatem, niezależnie od ich wielkości, są elementem o niezwykle istotnym znaczeniu dla kształtowania się sieci osadniczej, zarówno w makro-, jak i mikroskali. O ile szlaki wodne z oczywistych względów nie podlegały takim zmianom, o tyle lądowe ewoluowały, łącząc ze sobą mniejsze i większe osiedla w ramach zmieniającej się w czasie sieci osadniczej. Rekonstrukcja tych drugich jest więc trudniejszym zadaniem, przy którego realizacji konieczne jest uwzględnienie szeregu czynników natury przyrodniczej i kulturowej. Celem niniejszego artykułu, prócz określenia najstarszych struktur osadniczych, jest próba odtworzenia przebiegu szlaków o większym zasięgu, funkcjonujących na terenach położonych na zachód od Poznańskiego Przełomu Warty i łączących je z sąsiadującymi obszarami w starszych fazach wczesnego średniowiecza. Podstawę stanowiła analiza rozmieszczenia pozostałości osadnictwa $\mathrm{z}$ tego okresu i odniesienie jej do fizjografii zachodniej Wielkopolski. Zasadniczą bazę informacyjną tworzyły dane zgromadzone w ramach Archeologicznego Zdjęcia Polski, uzupełnione $\mathrm{w}$ sporym zakresie wynikami kwerendy prowadzonej $\mathrm{w}$ archiwum Wojewódzkiego Konserwatora Zabytków w Poznaniu (do roku 2013), w mniejszym stopniu materiałami publikowanymi i sporadycznie informacjami od autorów badań. Pod uwagę wzięto zasadniczo stanowiska z faz A, B i B/C (wg periodyzacji Witolda Hensla; 1950, s. 5 i $\mathrm{nn}$.), z zachowaniem nomenklatury stosowanej przez autorów badań, a dla późniejszego okresu wyłącznie grody „plemienne”. Pomijając tu kwestię określenia „faza A”, stosowanego niekiedy w literaturze dla określenia najstarszych wielkopolskich materiałów, mamy zasadniczo do czynienia z zespołami datowanymi na okres od około połowy VII stulecia. Wyznaczenie początków zasiedlenia Wielkopolski we wczesnym średniowieczu na ten czas odpowiada ustaleniom dokonanym na podstawie badań wykopaliskowych prowadzonych choćby na Śląsku i ziemi lubuskiej - daty uzyskane na podstawie analizy dendrochronologicznej ${ }^{1}$ tamtejszych drewnianych cembrowin studni wyjątkowo jedynie określane są na schyłek 1. połowy VII wieku². Górną granicę czasową wyznacza połowa $\mathrm{X}$ wieku, a więc okres upadku sieci grodowej, zastąpionej nową dla naszych rozważań organizacją terytorialną wprowadzoną przez państwo piastowskie. Dostępne informacje posłużyły utworzeniu mapy, na której zamieszczono punkty uwzględniające podział na stanowiska z faz A-B (do VIII wieku),

${ }^{1}$ Wyniki analiz 14C niestety dają na tyle duże przedziały czasowe, sięgające niekiedy 150-200 lat, że często nie da się na ich podstawie uściślić, czy też zweryfikować datowania metodami archeologicznymi.

${ }^{2} \mathrm{Na}$ VII wiek datowane są studnie odkryte w Polwicy, gm. Domaniów (677 AD), Sadkowie, gm. Kąty Wrocławskie (670 AD i $678 \mathrm{AD}$ ); w szerokich ramach 635-777 datowana jest cembrowina odkryta w Międzyrzeczu (szerzej na ten temat Pawlak i Pawlak 2018a, s. 73). 
B/C oraz ogólnie ze „starszych faz”. Najmłodszy element na mapie stanowią grody, które utworzyły dość regularną sieć odpowiadającą zasadniczo starszym strukturom osadniczym - wyjątek w tym względzie stanowią pojedyncze obiekty położone na Równinie Opalenickiej i w Obornickiej Dolinie Warty. Ich lokalizacja podkreśla więc trwałość niektórych ośrodków osadniczych, które z rozmaitych względów przekształciły się w ośrodki centralne lub przeciwnie - wskazuje rejony zasiedlone w młodszym okresie.

Granice interesującego nas regionu wyznaczają doliny Warty i Obry w ich środkowych i dolnych odcinkach. O ile pierwsza z rzek tworzyła dość wąską dolinę, rozlewając się szeroko dopiero w okolicach Sierakowa, o tyle „strugi i błota, które zowią Obrą" (Surowiecki 1811, s. 81), na całej niemal długości stanowiły rozległą i trudną do przebycia przeszkodę. Po wiek XIX, kiedy rozpoczęto na większą skalę jej meliorację, stanowiła naturalną zachodnią granicę Wielkopolski, nie mniej rozległą i „dojmującą” niż położona dalej na zachód i postrzegana standardowo jako graniczna dolina Odry. Opis Wawrzyńca Surowieckiego przybliża wygląd rzeki, obecnie w niczym nie przypominającej tej, która niegdyś rozdzielała obszary opisywane jako Wielkopolska zachodnia, południowa czy ziemia lubuska: „Nie masz rzeki, która by wylewami swemi tyle czyniła szkody krajowi naszemu, ile czyni Obra [...]. Bez koryta, bez spadku, wody jej, błąkając się na wszystkie strony, podmakają niezmierne równiny, i zamieniają je w niedostępne strugi i błota. Tam gdzie uprawne zagony mogłyby rolnikowi stokrotne wydawać żniwo [...], tam rozlane wody zgnilizną rozkisiałej ziemi, albo zarażają zdrowe powietrze, albo szkodliwe tylko rozkrzewiają zielska" (Surowiecki 1811, s. 74). Mapy fizjograficzne doskonale ilustrują odrębność tej części Wielkopolski, wydzielonej zwłaszcza od południa, zachodu i północy szerokimi i podmokłymi dolinami. Ten zwarty obszar jest jednak dość zróżnicowany pod względem zasiedlenia w starszych fazach wczesnego średniowiecza.

Skartografowanie stanowisk położonych w centralnej Wielkopolsce pozwala na wyodrębnienie kilku skupisk, których główną oś wyznaczają rzeki lub rynny jeziorne (najintensywniejsze wyznaczają górne odcinki Głównej i Cybiny oraz zachodnia część Pojezierza Gnieźnieńskiego; mniejsze, lecz wyraźne skupiska wydzielają się w zachodniej części Kotliny Śremskiej, na obszarze pomiędzy rynną jezior kórnickich a Moskawą, w okolicach ujścia Średzkiej Strugi do Warty oraz w południowej części Równiny Wrzesińskiej (Pawlak i Pawlak 2018a, s. 46, ryc. 1). Analiza rozmieszczenia stanowisk w Wielkopolsce zachodniej nie daje tak klarownego obrazu - po części wynika to ze stanu badań powierzchniowych, które - jak już wspomniano - stanowiły podstawę zestawienia, znacznie większego zalesienia tych obszarów i prozaicznie mniejszej liczby inwestycji, przy okazji

\footnotetext{
${ }^{3}$ Ostatnia kategoria (bardzo często stosowana na arkuszach AZP) stanowi spory problem, pod określeniem tym kryją się bowiem dość zróżnicowane pod względem chronologicznym materiały, które w części przypadków sięgają X wieku.
} 
których rozpoznawane są już znane lub nowo odkryte stanowiska. W większości uwagę badaczy skupiały grodziska, a więc obiekty o nieco młodszej metryce i większej atrakcyjności z punku widzenia oczekiwanych wyników. Sporym zainteresowaniem cieszył się zniszczony w XIX wieku obiekt w Pawłowicach, położony na trakcie wodnym Bogdanki i Samicy Kierskiej, w którym upatrywano związków z ośrodkiem poznańskim (Kara 2016, s. 101; Kóčka-Krenz 2005, s. 27). W ramach programu weryfikacji grodzisk realizowanego od 1976 roku przez Państwową Akademię Nauk w Poznaniu przeprowadzono sondażowe badania o niewielkim zakresie na wszystkich obiektach położonych po zachodniej stronie Poznania (Kurnatowska i Łosińska 1985). Badania o szerszym zakresie, które przede wszystkim pozwalały na precyzyjniejsze datowanie, objęły zaledwie kilka grodzisk: Rudki, Jastrowie-Ostrolesie i Ostroróg w powiecie szamotulskim (Pietrzak 2003), oraz w dużej części Dąbrówkę ${ }^{4}$ w powiecie poznańskim (Pawlak i Pawlak 2019, s. 491-497). Nieco okazalej prezentują się badania na osadach otwartych; ich rozpoznanie wykopaliskowe zawdzięczamy zazwyczaj realizowanym inwestycjom zarówno o niewielkim zasięgu, jak i obejmującym wielohektarowe powierzchnie. Dane zgromadzone w ramach programu AZP oraz pochodzące z badań wykopaliskowych dostarczają informacji o ponad 130 stanowiskach, których datowanie ustalono na okres między połową VII a schyłkiem VIII stulecia (należy tu wszakże uwzględnić wspominany wyżej problem kategorii „starsze fazy”). Listę tę uzupełniają grodziska - choć datowane są na młodszy okres, stanowiły ośrodki centralne wspólnot terytorialnych, o starszych lub młodszych tradycjach; umożliwiają one pełniejszą analizę samego osadnictwa, jego przemian i powiązań pomiędzy kolejnymi skupiskami.

Obraz uzyskany po skartografowaniu stanowisk, pomimo swej niedoskonałości, pozwala na podjęcie próby rekonstrukcji rozmieszczenia osadnictwa na terenach położonych po zachodniej stronie Poznańskiego Przełomu Warty w starszych fazach wczesnego średniowiecza. Uwagę zwraca brak wyraźnych koncentracji osad, choć zdecydowana większość stanowisk (62\%) jest położona we wschodniej części tego regionu, na powierzchni ponad $100000 \mathrm{~km}^{2}$, pomiędzy Poznańskim Przełomem Warty a doliną Samicy Stęszewskiej i Samy, nie przekraczając zasadniczo wyznaczonych przez nie granic (ryc. 1). Analizując rozmieszczenie stanowisk, nie sposób nie zauważyć silnej korelacji pomiędzy nimi a siecią rzeczną. Główny jej element stanowią swego rodzaju arterie wyznaczone przez biegi Samy i Samicy Stęszewskiej oraz Bogdanki, Samicy Kierskiej i Pamiątkowskiej. Pierwsza prowadzi od Kanału Mosińskiego łączącego Wartę z Obrą, druga od ujścia dwóch dużych prawobrzeżnych dopływów: Cybiny i Główny - obie wiodą ku północy, uchodząc do Warty poniżej Obrzycka. Główną sieć uzupełniają pomniejsze cieki; poczynając od zachodu, jest to Kanał Trzcieliński, który przez rynnę Jezior Chomęcickiego,

\footnotetext{
${ }^{4} \mathrm{Na}$ terenie grodu trwają badania archeologiczne związane $\mathrm{z}$ budową obiektów przemysłowych, które pokryją jego ostatnią, zachodnią część.
} 
Rosnowskiego i Jarosławieckiego uchodzi do Warty poniżej Puszczykowa, Wirynka, Strumień Junikowski wraz ze Skórzynką i Kotówką, a powyżej Bogdanki Różany Potok oraz bezimienny ciek ze źródłami w rejonie Biedruska (ryc. 2). Co ciekawe, osady rejestrowane są jedynie przy części z nich. Obserwacja ta może skłaniać do przypuszczeń, że o ile część rzek skupiała wzdłuż swoich dolin osadnictwo, o tyle inne wyznaczały swego rodzaju rejony graniczne, które pozostawały niezasiedlone. Przyjmując taką interpretację, można podjąć próbę wydzielenia kilku skupisk osadniczych:

1) pierwsze można wyznaczyć w górnym odcinku Samicy Stęszewskiej, w rejonie Jezior Wielkowiejskiego, Tomickiego i Niepruszewskiego; dzięki połączeniom wodnym jest skomunikowana z ujściem Mogilnicy i Obrą na południu oraz z Samą i Wartą na północy (ryc. 1, punkty 71-82);

2) niezbyt rozległe skupisko osad położone jest nad Samą powyżej Jeziora Lusowskiego (punkty 66-70, być może łącznie 64-65);

3) kolejne tworzą osady położone w górnym biegu Wirynki i wzdłuż jej dopływów (punkty 51-55). Jego zachodnią granicę wyznacza Kanał Trzcieliński, wschodnią - szeroka dolina Strumienia Junikowskiego;

4) najliczniejsze skupisko stanowisk datowanych na starsze fazy wczesnego średniowiecza notujemy wzdłuż doliny Warty, choć wpływ na ten obraz ma zaawansowany stan rozpoznania rejonów po obu jej brzegach. W jego ramach można wyróżnić pomniejsze koncentracje: a) rejon w północnej części południkowego odcinka Warty, poniżej ujścia Trojanki i Rowu Północnego/Pstrągowego (punkty 10-15), b) tereny zajęte obecnie przez poznańskie dzielnice: Umultowo i Naramowice oraz położone na wschodnim brzegu Warty, w Kicinie i Owińskach; jego granice zdają się zamykać między Jeziorem Glinowieckim i wypływającym z niego strumieniem na północy i Bogdanką na południu (punkty 16-35), c) w rejonie ujścia Cybiny ${ }^{5}$, po prawej stronie Warty (punkty 37-39), d) w rejonie Lubonia i Poznania-Starołęki i Minikowa, powyżej ujścia Strumienia Junikowskiego i Kopli (punkty 40-47);

5) osady położone w górnych odcinkach Samicy Kierskiej i Pamiątkowskiej, począwszy od Jeziora Kierskiego (punkty 56-61); zarówno od południa, jak i północy skomunikowane z Wartą w jej południkowym i równoleżnikowym biegu.

Poza strefą zamkniętą dolinami Warty i Samicy Stęszewskiej oraz Samy wyróżniają się tylko trzy rejony o większym nagromadzeniu osadnictwa:

1) dolina Mogilnicy w rejonie ujścia do Obry, przynależna raczej strefie obrzańskiej (punkty 84-87); osady położone na północ od niej (punkty 83, 88-90) należy

\footnotetext{
${ }^{5}$ Uwagę zwraca zaledwie pojedyncze stanowisko odkryte u ujścia Bogdanki. Brak osad w tym rejonie można by przypisać zurbanizowaniu tego terenu (zajętego od XIII wieku przez Poznań), choć jednocześnie znane są z niego liczne stanowiska pradziejowe, świadczące o osadniczej „atrakcyjności” tej rzeki (Szałata, Makohonienko i Jasiewicz 2016).
} 


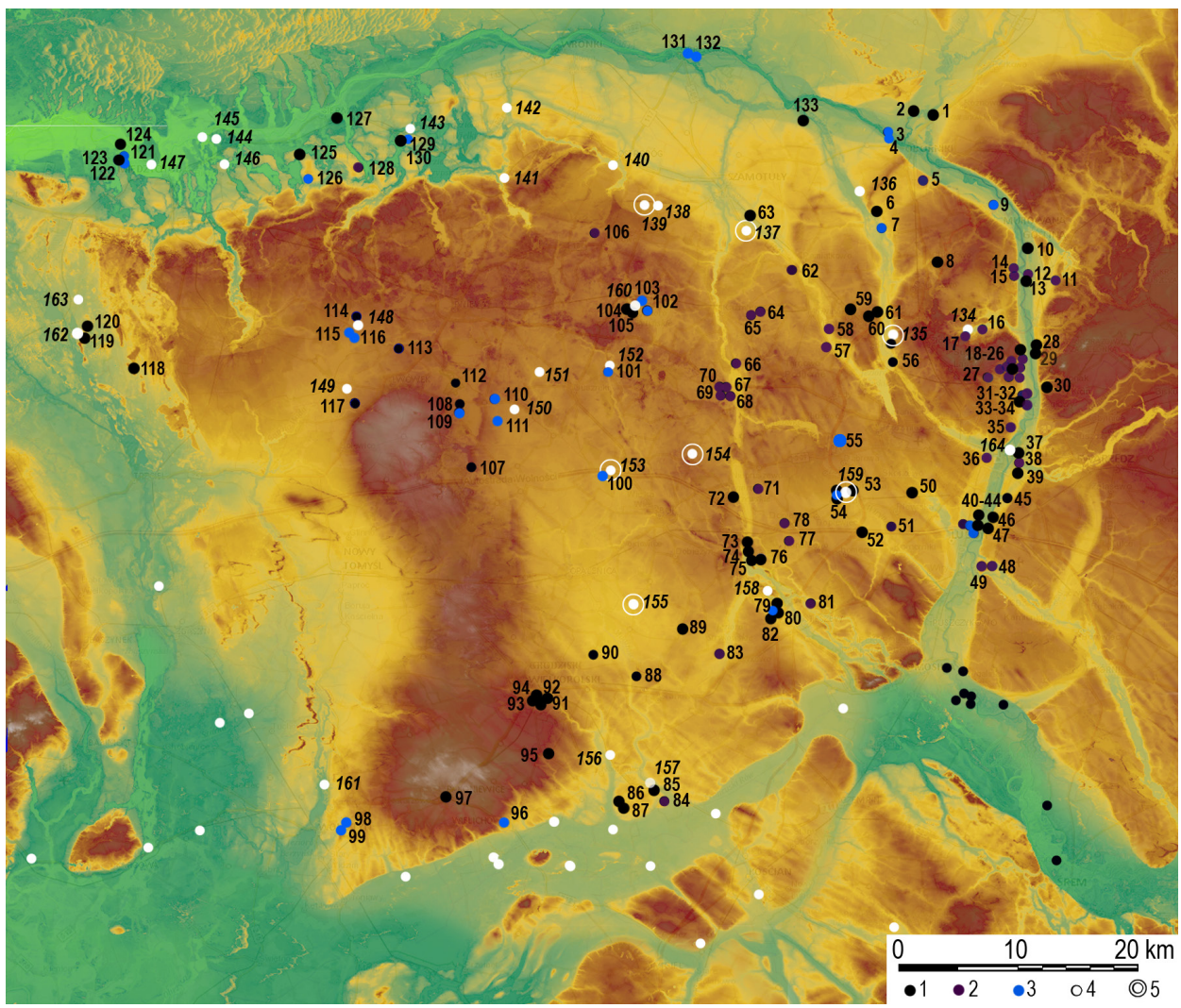

Ryc. 1. Rozmieszczenie stanowisk ze starszych faz wczesnego średniowiecza (1 - faza A-B, 2 - faza B/C, 3 - ogólnie starsze fazy, 4 - grodziska)

1. Kowanówko, gm. Oborniki, stan. 2; 2. Rudki, gm. Oborniki, stan. 1; 3. Oborniki, gm. loco, stan. 15 (3); 4. Oborniki, gm. loco, stan. (10); 5. Gołaszyn, gm. Oborniki, stan. 29; 6. Kowalewko, gm. Oborniki, stan. 10; 7. Wargowo, gm. Oborniki, stan. 4; 8. Chludowo, gm. Suchy Las, stan. 62; 9. Radzim, gm. Oborniki, stan. 2 (3); 10. Złotoryjsko, gm. Murowana Goślina, stan. 8; 11. Bolechowo, gm. Czerwonak, stan. 23; 12. Promnice, gm. Czerwonak, stan. 4; 13. Promnice, gm. Czerwonak, stan. 2; 14. Biedrusko, gm. Suchy Las, stan. 1; 15. Biedrusko, gm. Suchy Las, stan. 8; 16. Biedrusko, gm. Suchy Las, stan. 50; 17. Biedrusko, gm. Suchy Las, stan. 27; 18. Poznań-Nowa Wieś, stan. 11; 19. Poznań-Umultowo, stan. 24; 20. Poznań-Umultowo, stan. 20; 21. Poznań-Umultowo, stan. 16; 22. Poznań-Umultowo, stan. 21; 23. Poznań-Umultowo, stan. 6; 24. Poznań-Morasko, stan. 31; 25. Poznań-Umultowo, stan. 11; 26. Poznań-Umultowo, stan. 10; 27. Poznań-Morasko, stan. 4; 28. Owińska, gm. Czerwonak, stan. 7; 29. Owińska, gm. Czerwonak, stan. 43; 30. Kicin, gm. Czerwonak, stan. 6; 31. Poznań-Naramowice, stan. 8; 32. Poznań-Umultowo, stan. 27; 33. Poznań-Naramowice, stan. 31; 34. Poznań-Naramowice, stan. 10; 35. Poznań-Szeląg, stan. 19; 36. Poznań (ul. Dominikańska 4), stan. 3; 37. Poznań (Brama Warszawska); 38. Poznań-Komandoria, stan. 1; 39. Poznań-Nowe Miasto, stan. 362 (ul. A. Baraniaka); 40. Poznań-Luboń, stan. 9b (stan. F); 41. Poznań-Luboń, stan. 7; 42. Poznań-Luboń, stan. 10; 43. Poznań-Luboń, stan. 22; 44. Poznań-Dębiec, stan. 17; 45. Poznań-Żegrze, stan. 11; 46. Poznań-Starołęka Mała, stan. 3; 47. Poznań-Minikowo, stan. 6; 48. Czapury, stan. 23; 49. Czapury, stan. 24; 50. Plewiska, gm. Komorniki, stan. 51; 51. Komorniki, gm. loco, stan. 39; 52. Głuchowo, gm. Komorniki, stan. 1; 53. Dąbrówka, gm. Dopiewo, stan. 1; 54. Dąbrówka, gm. Dopiewo, stan. 5; 55. Batorowo, 
gm. Tarnowo Podgórne, stan. 19; 56. Poznań-Psarskie, stan. 11; 57. Napachanie, gm. Rokietnica, stan. 47; 58. Mrowino, gm. Rokietnica, stan. 2; 59. Rokietnica, gm. loco, stan. 23; 60. Bytkowo, gm. Rokietnica, stan. 23; 61. Bytkowo, gm. Rokietnica, stan. 1; 62. Pamiątkowo, gm. Szamotuły, stan. 64; 63. Kąsinowo, Baborówko, gm. Szamotuły, domniemane stanowisko ofiarne; 64. Chlewiska, gm. Kaźmierz, stan. 48; 65. Dolne Pole, gm. Kaźmierz, stan. 19; 66. Kiączyn, gm. Kaźmierz, stan. 70; 67. Gaj Wielki, gm. Kaźmierz, stan. 71; 68. Gaj Wielki, gm. Kaźmierz, stan. 73; 69. Gaj Wielki, gm. Kaźmierz, stan. 52; 70. Gaj Wielki, gm. Kaźmierz, stan. 67; 71. Zborowo, gm. Dopiewo, stan. 26; 72. Niepruszewo, gm. Buk, stan. 49; 73. Tomice, gm. Dopiewo, stan. 1; 74. Tomice, gm. Dopiewo, stan 2; 75. Tomice, gm. Dopiewo, stan. 3; 76. Lisówki/Trzcielin, gm. Dopiewo, stan. 3; 77. Dopiewo, gm. loco, stan. 29; 78. Dopiewo, gm. loco, stan. 30; 79. Krąplewo, gm. Stęszew, stan. 28; 80. Krąplewo, gm. Stęszew, stan. 29; 81. Dębienko, gm. Stęszew, stan. 2; 82. Zamysłowo, gm. Stęszew, stan. 9; 83. Januszewice, gm. Granowo, stan. 2; 84. Łęki Małe, gm. Kamieniec, stan. 2;85. Wilanowo, gm. Kamieniec, stan. 15; 86. Goździchowo, gm. Kamieniec, stan. (1); 87. Goździchowo, gm. Kamieniec, stan. (2); 88. Kotowo, gm. Grodzisk Wlkp, 89. Strzępiń, gm. Granowo, stan. 2 (1); 90. Snowidowo, gm. Grodzisk Wlkp. stan. 6; 91. Grodzisk Wielkopolski, stan. 2; 92. Grodzisk Wielkopolski, stan. 3; 93. Grodzisk Wielkopolski, stan. 4; 94. Grodzisk Wielkopolski, stan. 5; 95. Zielęcin, gm. Wielichowo stan.15; 96. Wielichowo, gm. loco, stan, 6; 97. Rakoniewice, gm. loco, stan. 1; 98. Komorowo, gm. Wolsztyn, stan. 1; 99. Komorowo, gm. Wolsztyn, stan. 2; 100. Sędzinko, gm. Duszniki, stan. 2; 101. Młynkowo, gm. Duszniki, stan. 2; 102. Komorowo, gm. Kaźmierz, stan. 1; 103. Komorowo, gm. Kaźmierz, stan. 1; 104. Piersko, gm. Kaźmierz, stan. (3); 105. Piersko, gm. Kaźmierz, stan. 2 (2); 106. Otorowo, gm. Szamotuły, stan. 66; 107. Głuponie, gm. Kuślin, stan. 6; 108. Pakosław, gm. Lwówek, stan. 3; 109. Pakosław, gm. Lwówek, stan 2; 110. Brody, gm. Lwówek, stan 5a; 111. Brody, gm. Lwówek, stan 10; 112. Zgierzynka, gm. Lwówek, 35; 113. Konin, gm. Lwówek, stan. 1; 114. Linie, gm. Lwówek, stan. 3; 115. Linie, gm. Lwówek, stan. 6; 116. Linie, gm. Lwówek, stan. 9; 117. Grońsko, gm. Lwówek, stan. 10; 118. Silna, gm. Pszczew, stan. 1; 119. Pszczew, stan. 6 (6); 120. Pszczew, stan. 13 (9); 121. Muchocin, gm. Międzychód, stan. 1 (1); 122. Muchocin, gm. Międzychód, stan. 4 (2); 123. Muchocin, gm. Międzychód, stan. 7 (5); 124. Mierzyn, gm. Międzychód, stan. 1; 125. Śrem, gm. gm. Sieraków, stan. 1; 126. Góra, gm. Sieraków, stan. 3; 127. Sieraków, gm. loco, stan. 1; 128. Grobia, gm. Sieraków, stan. (1); 129. Ryżyn, gm. Sieraków, stan. 2; 130. Ryżyn, gm. Sieraków, stan. 3; 131. Obrzycko, gm. loco, stan. 1; 132. Obrzycko, gm. loco, stan. (3); 133. Sławienko, gm. Oborniki, stan 198; Grodziska: 134. Glinno, gm. Suchy Las; 135. Pawłowice, gm. Rokietnica; 136. Objezierze, gm. Oborniki; 137, Kąsinowo; 138. Jastrowie-Ostrolesie; 139. Rudki, gm. Szamotuły; 140. Ostroróg, gm. Loco; 141. Nojewo, gm. Pniewy; 142. Wróblewo, gm. Wronki; 143. Ryżyn, gm. Chrzypsko Wielkie; 144. Aleksandrowo; 145. Zielona Chojna; 146. Kolno; 147. Muchocin, gm. Międzychód; 148. Linie; 149. Komorowo; 150. Bródki, gm. Lwówek; 151. Niewierz; 152. Młynkowo/Wilczyna; 153. Sędzinko, gm. Duszniki; 154. Brzoza, gm. Duszniki; 155. Dakowy Mokre, gm. Opalenica; 156. Kamieniec, gm. Loco; 157. Konojad, gm. Kamieniec; 158. Nowa Wieś-Krąplewo, gm. Stęszew; 159. Dąbrówka, gm. Dopiewo; 160. Komorowo, gm. Kaźmierz; 161. Chorzemin, gm. Wolsztyn; 162. Pszczew, półwysep Katarzyna; 163. Pszczew, gm. loco; 164. Poznań-Ostrów Tumski. Legenda: 1 - relikty osadnictwa z fazy B; 2 - relikty osadnictwa ze „starszych faz wczesnego średniowiecza"; 3 relikty osad z faz B/C; 4 - grody; 5 - grody o dużych rozmiarach. Oprac. E. Pawlak na podkładzie numerycznego modelu terenu (źródło: www.geoportal.gov.pl)

rozpatrywać w kontekście późniejszych grodów i upatrywać w nich odrębnej struktury osadniczej;

2) rejon górnego odcinka Mogilnicy i Czarnej Wody połączonych Jeziorem Konińskim (punkty 107-117);

3) osady zlokalizowane po południowej stronie Warty (w jej współczesnym biegu) w rejonie Sierakowa i Międzychodu (punkty 121-132).

Zaprezentowany opis pozwala więc wskazać cztery główne obszary skupiające osadnictwo, którego datowanie odnosimy do starszych faz wczesnego średniowiecza. 


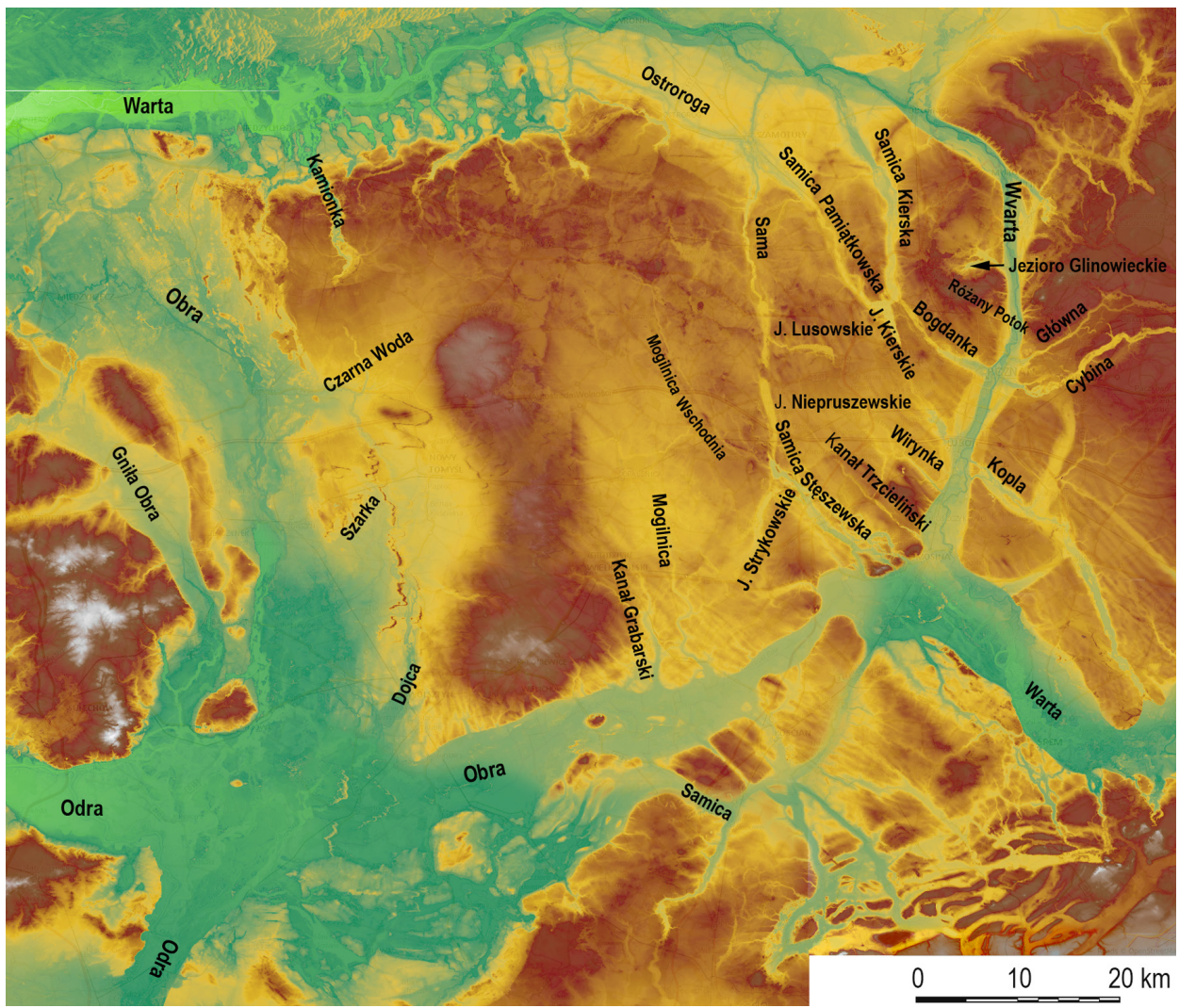

Ryc. 2. Sieć hydrograficzna Wielkopolski na zachód od Poznańskiego Przełomu Warty. Oprac. E. Pawlak, na podkładzie numerycznego modelu terenu (źródło: www. geoportal.gov.pl)

Obraz ten ulega pewnym modyfikacjom przy uwzględnieniu podziału na stanowiska datowane do końca fazy B, ogólnie datowane na „starsze fazy” oraz przełom B/C. Wziąwszy pod uwagę wyłącznie najstarsze stanowiska, widzimy je w pasie o szerokości 10-16 km położonym po północnej stronie Obry (od doliny Mogilnicy) i zachodniej stronie Warty, rozlokowane wzdłuż ich głównych dopływów. Niewielkie zgrupowanie znajduje się także w rejonie Lwówka, na północ od Wału Lwówecko-Rakoniewickiego (górne odcinki Mogilnicy i Czarnej Wody) i w Obornickiej Dolinie Warty poniżej Sierakowa. Rozległe anekumeny stanowi Równina Opalenicka, Wał Lwówecko-Rakoniewicki, Równina Nowotomyska i Pojezierze Międzychodzko-Pniewskie.

Badania powierzchniowe niekiedy dają możliwość uchwycenia kilku podobnie datowanych stanowisk, które pozwalają domyślać się w ich rejonie albo rozleglejszego osiedla, albo też kilku, funkcjonujących przez dłuższy czas na dość zwartym terytorium, tak jak to obserwujemy w rejonie Różanego Potoku, Jezior Kierskiego, 


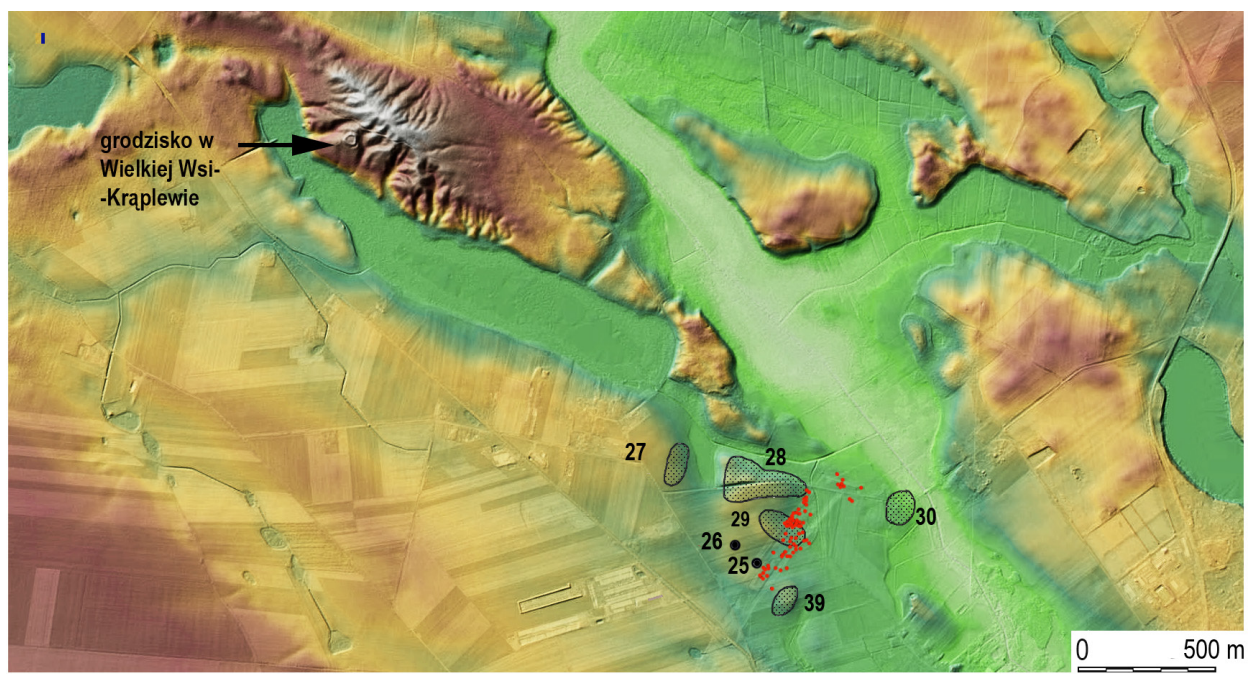

Ryc. 3. Rozmieszczenie stanowisk ze starszych faz wczesnego średniowiecza w okolicach Krąplewa nad Samicą Stęszewską. Czerwonymi punktami zaznaczono obiekty rozpoznane podczas badań w latach 2015-2017. Oprac. E. Pawlak na podkładzie numerycznego modelu terenu (źródło: www. geoportal.gov.pl)

Tomickiego, Bytyńskiego czy nad Samą powyżej Jeziora Lusowskiego. Jednak określenie sposobu użytkowania tej przestrzeni, trwałości jej zasiedlenia jest możliwe wyłącznie na podstawie rozpoznania wykopaliskowego. Z terenów położonych na zachód od Poznańskiego Przełomu Warty znamy zaledwie dwa stanowiska, które wyraźnie odbiegają od typowego dla tego okresu schematu niewielkiego osiedla o rozproszonej zabudowie - Krąplewo, gm. Stęszew, nad Samicą Stęszewską ${ }^{6}$ i Wilanowo, gm. Kamieniec, położone na skraju doliny Mogilnicy tuż przy jej ujściu do Obry. Na stanowisku 29 w Krąplewie rozpoznano 108 obiektów ${ }^{7}$ rozlokowanych na południowym skraju osady, która zajmowała znacznie rozleglejszy teren (Pawlak 2016). Wziąwszy pod uwagę rozmieszczenie najbliższych stanowisk, z których pochodzi podobnie datowany materiał oraz ukształtowanie terenu, możemy przypuszczać, że zasiedlono całą kępę wyniesioną nieznacznie ponad dno doliny oraz być może skraj stoku (ryc. 3). Nawet jeśli nie wszystkie obiekty były użytkowane jednocześnie, dość wąskie ramy chronologiczne osady wyznacza z jednej strony seria dat uzyskanych na podstawie analizy dendrochronologicznej budulca kilku

${ }^{6}$ Dziękuję Markowi Żółkiewskiemu za możliwość wykorzystania materiałów z badań prowadzonych przez Centrum Archeologiczne Fundacji Uniwersytetu im. Adama Mickiewicza w Poznaniu na potrzeby niniejszego artykułu.

7 Po Markowicach w gm. Kleszczewo (stan. 21 i 26) jest to druga osada w Wielkopolsce co do liczby rozpoznanych obiektów i powierzchni. 
studni, a z drugiej brak elementów w wytwórczości garncarskiej, którym można by przypisać młodszą metrykę. Czas funkcjonowania osady przypada na VIII stulecie, choć pierwotnie ze względu na niezwykle archaiczny charakter naczyń (ponad $70 \%$ naczyń całkowicie ręcznie lepionych, w pozostałych niewielki zakres użycia koła garncarskiego, znikomy udział egzemplarzy dekorowanych) jej początki wyznaczono na mniej więcej połowę VII wieku. Obecność zarówno na stanowisku 29, jak i na sąsiednich młodszych materiałów, datowanych na okres od połowy IX do połowy X wieku oraz pochodzących z 3. ćwierci XII do połowy XIII wieku ${ }^{8}$ wskazuje, że rejon Krąplewa musiał wyróżniać się szczególnymi walorami, które sprzyjały osadnictwu. Prócz korzystnych warunków przyrodniczych wskazać należy dogodne położenie komunikacyjne w dolinie Samicy Stęszewskiej, powyżej jej dolnego odcinka, na którym wraz z Kanałem Trzcielińskim tworzy niezwykle rozległą i trudną do przebycia dolinę (o szerokości od 3 do ponad $4 \mathrm{~km}$ ). Układ wyniesień w obrębie doliny tworzył w rejonie Krąplewa możliwość stosunkowo łatwego pokonania rozlewisk - można by więc upatrywać właśnie w tym rejonie skrzyżowania szlaku wodnego ze szlakiem lądowym.

Równie dogodne położenie odnosi się do osady w Wilanowie, gm. Kamieniec (Krzyszowski 2018). W ramach odsłoniętej części stanowiska zadokumentowano 77 obiektów datowanych na VII-VIII wiek, które zajmowały obszar rozpościerający się wzdłuż doliny Mogilnicy, tuż u jej ujścia do Obry (w odległości niespełna 1,5 km; ryc. 4). Lokalizacja osady na „skrzyżowaniu” tych dwóch niezwykle ważnych szlaków wodnych z pewnością sprzyjała powstaniu tak rozległego osiedla. W przypadku Wilanowa przy doborze miejsca pod zasiedlenie mogły decydować względy nie tylko praktyczne - Andrzej Krzyszowski wskazuje na kontekst kurhanów kultury unietyckiej, stanowiących charakterystyczny element krajobrazu, któremu także wczesnośredniowieczne społeczności mogły przydawać specjalne znaczenie, być może związane ze sferą wierzeń.

Prócz obu wymienionych osad można wskazać jeszcze jedną, choć ta została rozpoznana w niepomiernie mniejszym stopniu. W Bytkowie, gm. Rokietnica, na południowym skraju wielohektarowych wykopów archeologicznych odsłonięto zaledwie 18 obiektów, usytuowanych w jednej linii, prostopadle do Samicy Kierskiej. Ubogi zestaw form wykonanych bez użycia koła lub obtaczanych w niewielkim tylko zakresie (odpowiednio 25,8\% i 48,4\%), minimalny udział naczyń zdobionych, wskazywały na 1 . połowę VIII wieku, jednak obecność w jednym z obiektów ostrogi nie uprawnia do datowania wcześniejszego niż druga połowa tego stulecia (Pawlak 2016). Lokalizacja i kontekst sąsiednich stanowisk mogą sugerować znacznie większy zasięg osady, która prawdopodobnie rozciągała się na zachodnim stoku doliny. Na południe od Bytkowa rzeka tworzy ciąg jezior i mokradeł, natomiast w rejonie osady wysunięty w dolinę cypel dawał możliwość dogodnej przeprawy

${ }^{8}$ Kontynuacja osady z młodszych faz wczesnego średniowiecza położona jest na przeciwległym stoku doliny (stan. 39; E. Pawlak 2018b, s. 145-157). 

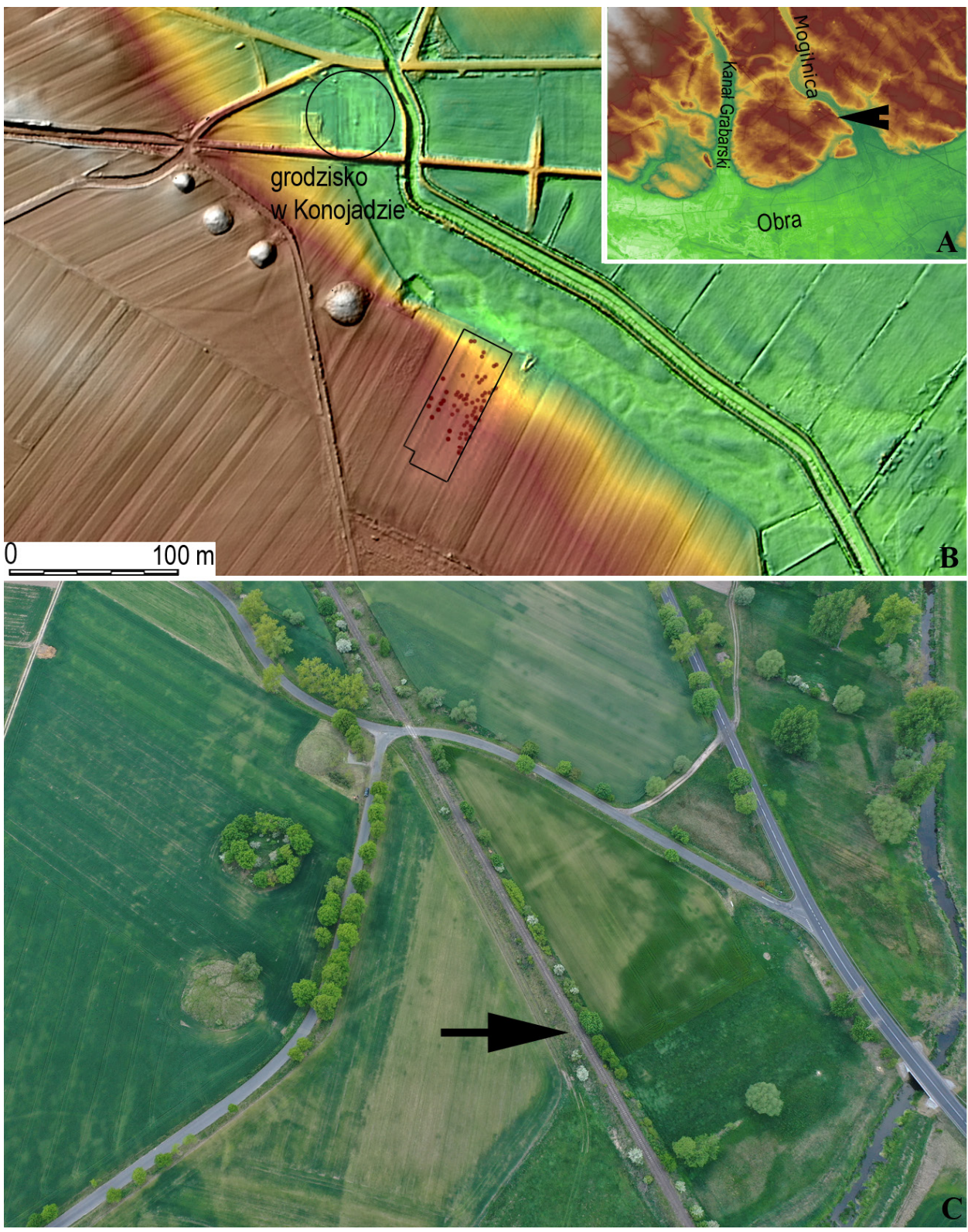

Ryc. 4. Pozostałości osady ze starszych faz wczesnego średniowiecza w okolicach Wilanowa nad Mogilnicą na podkładzie numerycznego modelu terenu (oprac. E. Pawlak na podstawie A. Krzyszowskiego 2018) oraz pozostałości grodziska i osady przygrodowej w Konojadzie (fot. M. Krzepkowski) 
na jej wschodni brzeg. Wydaje się więc, że osada zajęła teren położony w sąsiedztwie brodu, czy też miejsca, w którym przeprawa sprawiała najmniej trudu9, a więc ponownie w rejonie, gdzie krzyżowały się szlaki wodne i lądowe.

Wziąwszy pod uwagę datowanie wszystkich trzech stanowisk, uwagę zwraca ceramika, która niemal do końca VIII wieku wykazuje niezwykle archaiczne cechy odnoszące się do techniki wykonania, skromnego zestawu używanych form oraz niemal zupełnego braku zdobień. Zespoły naczyń o podobnych cechach odnoszono zazwyczaj do najstarszych stadiów wczesnego średniowiecza (datowanych na fazę A, A/B lub B w obowiązującej do dziś periodyzacji wczesnego średniowiecza w Wielkopolsce), a więc sięgających swymi początkami VI wieku (Kara 2008, s. 64 i nn.). Niemal wyłącznie mamy do czynienia z prostymi formami garnków; analogie do wielu z nich znajdujemy na ziemi lubuskiej, a więc na terenach położonych na zachód od dolnej Obry ${ }^{10}$. Szczególną uwagę zwracają naczynia zaliczone do typów H i K z Bytkowa (ryc. 5:1-6) i typu H z Krąplewa (ryc. 5:7-11), zbliżone do egzemplarzy pochodzących z Przewozu, gm. Bojadła, Kalska, gm. Sulechów, Sulechowa, gm. loco, Połupina, gm. Dąbie i Letnicy, gm. Świebodzin (E. Pawlak 2016, s. 154-157; Gruszka, Pawlak i Pawlak 2013). Wziąwszy pod uwagę, że ceramika często jest jedynym rodzajem przedmiotów codziennego użytku, który przetrwał do naszych czasów i zachował znamiona lokalnej stylistyki, to ów „lubuski trop” może wskazywać na kontakty także z dość odległymi obszarami ziemi lubuskiej.

Niestety, nie dysponujemy zbyt licznymi publikacjami dotyczącymi materiałów z terenów między Wartą a Obrą, które byłyby datowane na schyłek VIII lub 1. połowę IX wieku. Najliczniejsza kolekcja pochodzi z badań prowadzonych na stanowisku 2 w Dąbrówce, na którym zarejestrowano warstwy łączone z osadą poprzedzającą powstanie grodu. Niezwykle ciekawie prezentują się fragmenty naczyń, dla których analogii autorzy upatrują nie tylko w nieodległych Pawłowicach i Bninie (choć tam w obrębie nawarstwień o młodszej metryce), ale także na znacznie odleglejszej Opolszczyźnie (ryc. 10:4, 6; Pawlak i Pawlak 2019c, tabl. XL:6, XLIII:1). W marginalnym zakresie $\mathrm{w}$ zespole tym pojawiają się naczynia $\mathrm{w}$ typie Menkendorf i Feldberg, wskazując na coraz odleglejsze inspiracje w wytwórczości ceramicznej. Obce wpływy kulturowe widoczne są nie tylko w zakresie przedmiotów codziennego użytku, ale także w postaci wytworów elitarnych, do

${ }^{9}$ Badania geomorfologiczne przeprowadzone w rejonie stanowiska wykazały, że w czasie funkcjonowania osady ze schyłkowej epoki brązu i okresu halsztackiego dolinę Samicy wypełniało jezioro (Cież i Daraż 2010, ryc. 1). Nie określono, niestety, kiedy zarastanie dno doliny doprowadziło do jego zaniku, jednak użytkowane po czasy współczesne liczne stawy, położone na odcinku około $2 \mathrm{~km}$ w górę rzeki, począwszy od okolic stan. 1, wskazują, że także we wczesnym średniowieczu należy się liczyć z obecnością nie tyle rozlewisk i mokradeł, ile rozległego zbiornika wodnego. Przypuszczenie to wydaje się tym trafniejsze, że pod koniec XIX wieku, opisując okolicę pobliskiego pawłowickiego grodziska, wspominano o „osuszonym jeziorze” (zapewne w efekcie melioracji, Słownik... 1886, s. 910).

${ }^{10}$ Uwagi dotyczą jedynie stanowisk w Krąplewie i Bytkowie, ponieważ materiały ruchome z Wilanowa nie zostały jeszcze opublikowane. 

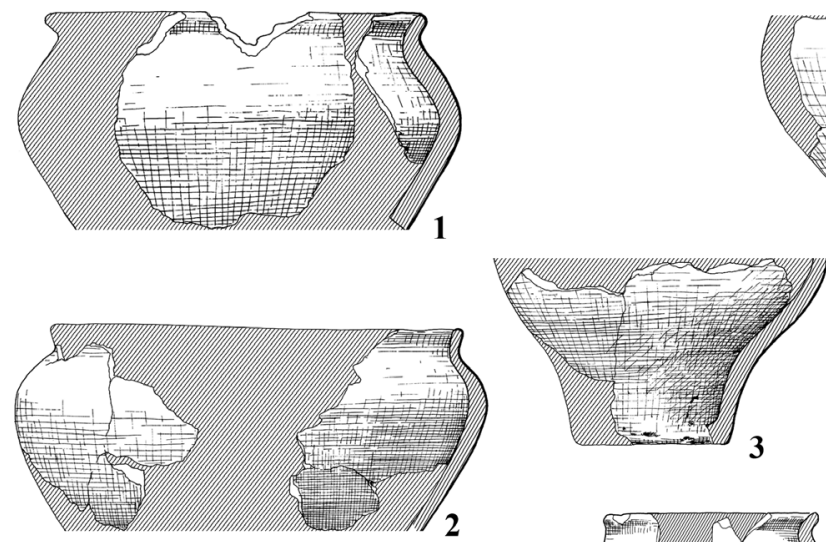

3
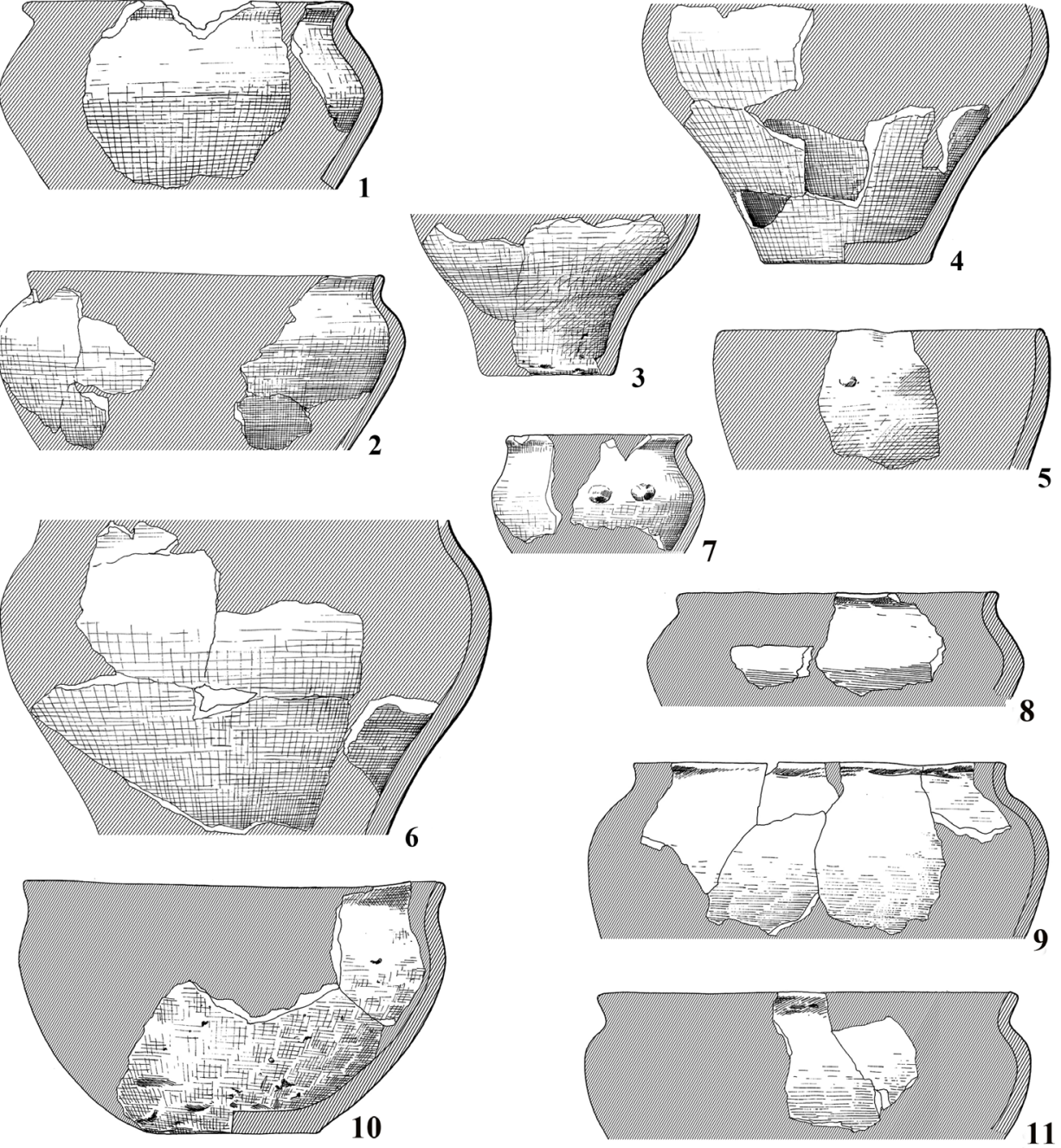

Ryc. 5. Wybór naczyń ze stanowisk w Bytkowie, gm. Rokietnica i Krąplewie, gm. Stęszew. Rys., oprac. E. Pawlak

których niewątpliwie można zaliczyć ostrogi. Z badań prowadzonych w ostatnich latach pochodzą aż trzy takie znaleziska (zaliczone do typu B wg Lidii Maćkowiak-Kotkowskiej i Jana Żaka, 1988, s. 31, 32), datowane na VIII wiek, i wszystkie grupują się na zwartym obszarze pomiędzy Wartą a Samą/Samicą Stęszewską (ryc. 6). Egzemplarze odkryte w Niepruszewie, gm. Buk, stan. 49 i Bytkowie, gm. Rokietnica, stan. 1, wyróżniają się dekoracjami - ramię kabłąka pierwszej zdobią ukośne rowki tworzące jodełkę, a bodziec dookolne rowki, natomiast w drugiej rowki pokrywają podstawę bodźca, a kabłąk na całej długości pokryty jest 

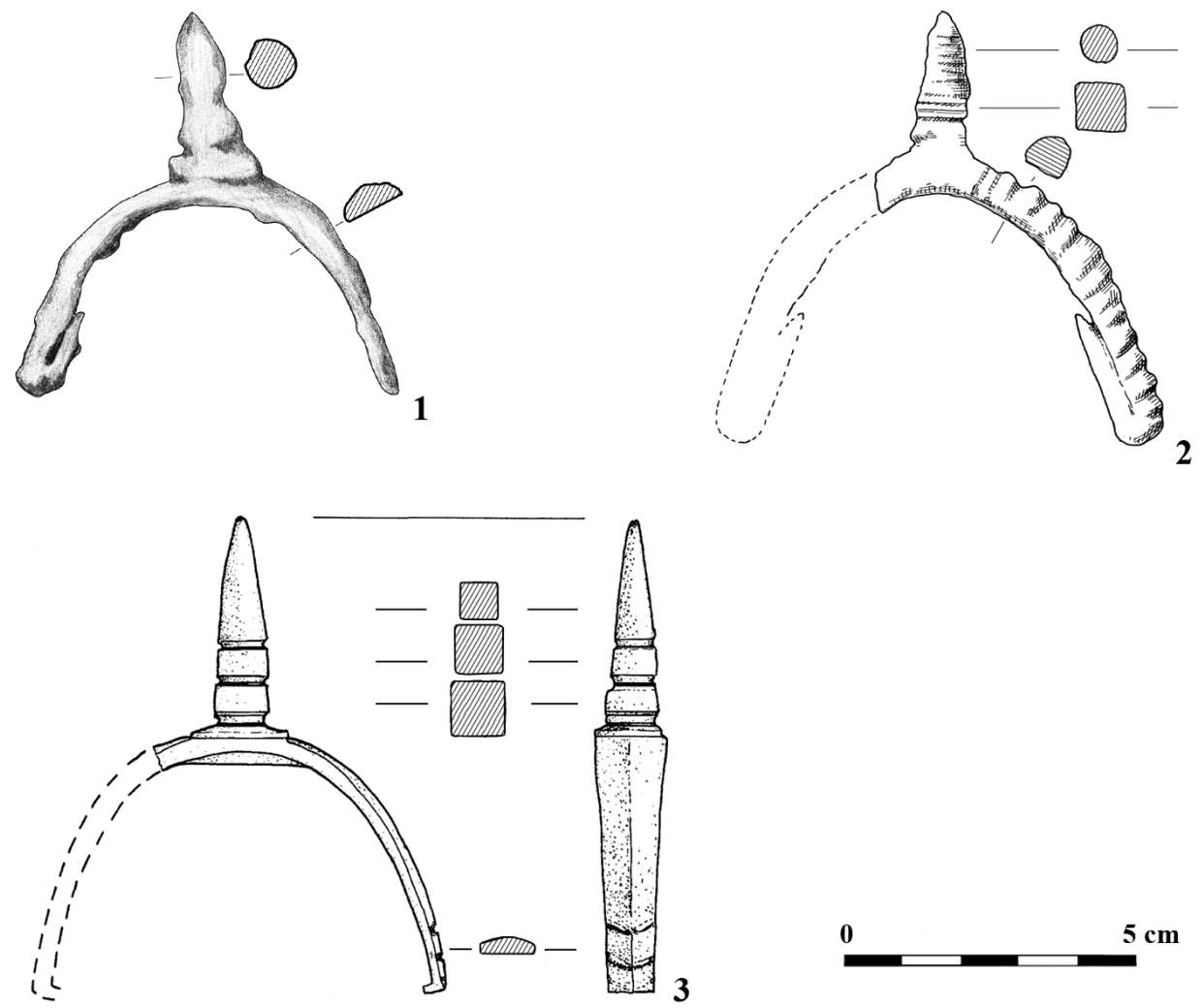

Ryc. 6. Ostrogi haczykowate z Poznania-Nowego Miasta, stan. 362, Bytkowa, stan. 1 i Niepruszewa, stan. 49 (wg Pawlak 2013, ryc. 18, Pawlak 2016, ryc. 27; Krzyszowski 2009, ryc. 27)

charakterystycznym puklowaniem (Krzyszowski 2009, s. 190, ryc. 27; Pawlak, 2016, s. 159, ryc. 27). Trzecia ostroga pochodzi z prawobrzeżnego Poznania, stan. 362, a jej jedyny element dekoracyjny stanowi profilowany bodziec (Pawlak 2013, s. 206, ryc. 18). Krzysztof Wachowski wskazywał na Pomorze i Nadłabie jako te rejony, przez które napływały do Wielkopolski ostrogi z plastyczną dekoracją w typie karolińskim (Wachowski 1992, s. 109-113). Z pewnością formująca się od początku VIII wieku strefa przybałtycka, zróżnicowana pod względem etnicznym i kulturowym, zunifikowana natomiast pod względem gospodarczym, wywierała ogromny wpływ także na krainy położone w głębi interioru (Łosiński 2008, s. 144).

Szukając szlaków, którymi napływały nie tylko konkretne przedmioty, ale także inspiracje dla wytwarzania podobnych w lokalnych warsztatach, należy ponownie przyjrzeć się rozmieszczeniu najstarszych stanowisk i formującym się już w początkowym etapie centrom osadniczym. To ich mieszkańcy byli odbiorcami napływających 
dóbr i wzorców i nie ulega chyba wątpliwości, że sami także przekazywali własne wytwory i własne pomysły „w drugą stronę”. Osady znaczą więc dawne trakty, których przebieg silnie determinowały warunki przyrodnicze. Analiza ich rozmieszczenia wskazuje na zależność między lokalizacją a przebiegiem głównych cieków regionu, które pełniły nie tylko funkcję gospodarczą, ale także komunikacyjną. W oczywisty sposób skomunikowane były ze sobą osiedla położone wzdłuż jednego wodnego szlaku, a wziąwszy pod uwagę znacznie wyższy poziom wód gruntowych, także podróże pomiędzy sąsiadującymi dolinami nie sprawiały większego problemu. Zapewne w zależności od celu użytkowano zróżnicowane pod względem rozmiarów łodzie. Można przyjąć, że w codziennym użytkowaniu dominowały znacznie mniejsze okazy, zdolne pomieścić kilka osób, lub nawet jednoosobowe. Relikty tego rodzaju łodzi datowanej na $\mathrm{X}$ wiek, liczącej zaledwie 2,5 m długości i 1 m szerokości, odkryto na poznańskiej Śródce w 2017 roku (ryc. 8; Pawlak i Pawlak 2018b, s. 182).

Na ogromne znaczenie rzek jako szlaków komunikacyjnych zwrócili uwagę Zofia i Stanisław Kurnatowscy, podkreślając ich ogromną rolę w funkcjonowaniu pradziejowych i wczesnośredniowiecznych społeczności. Niewątpliwie rzeki stanowiły wygodny sposób szybkiego przemieszczania się nawet na duże odległości, transportu znacznych ładunków przy zaangażowaniu niewielu osób i użyciu niepomiernie mniejszego wysiłku niż w przypadku transportu lądowego (Kurnatowscy 1996). Na obszarach szczególnie obfitujących w rozlewiska, czy płynące wieloma korytami rzeki i strugi, korzystanie z łodzi było wygodnym sposobem poruszania się w ciągu całego roku. Warto przy tym pamiętać, że i wodne szlaki, podobnie jak lądowe, wymagały stałej troski polegającej choćby na usuwaniu niesionych przez nurt przeszkód, zwalonych pni itp., które skutecznie utrudniały podróż. Niewiele jednak regionów przypominało poleskie czy nadobrzańskie bagna, umożliwiając swobodną pieszą podróż. Można więc założyć, że poszczególne wspólnoty użytkowały trakty lądowe nie tylko służące krótkodystansowej komunikacji, ale także szlaki o dłuższym zasięgu, które łączyły zarówno sąsiadujące ze sobą terytoria, jak $\mathrm{i}$ te bardziej od siebie oddalone. Pierwsze pokrywały zapewne gęstą siecią obszar opola i wiązały się na przykład z uprawą, wypasem i podobnego rodzaju działalnością gospodarczą, czy wreszcie kontaktami pomiędzy poszczególnymi osiedlami wchodzącymi w skład danej jednostki terytorialnej. Drugich należy upatrywać pomiędzy głównymi skupiskami osad lub osadami wyróżniającymi się rozmiarami.

O ile południkowy układ cieków charakterystyczny dla tych terenów ułatwiał podróże w kierunku na północ i południe, o tyle wędrówki skierowane na wschód lub zachód wydają się bardziej wymagające. Spore utrudnienie mogła stanowić podróż bezpośrednio wzdłuż Obry. Liczba uchodzących do niej mniejszych i większych dopływów wzrastała bowiem wraz ze zbliżaniem się do rzeki - ich grząskie ujścia, liczne rozwidlone koryta i niekiedy strome stoki stanowiły w wielu przypadkach istotne przeszkody, zwłaszcza kiedy uświadomimy sobie, że szerokość 
tych niewidocznych dziś dolin mogła sięgać od kilkuset metrów do kilku kilometrów (dolina Bogdanki w pobliżu Warty wynosi $1 \mathrm{~km}$, podobną szerokość ma dolina Strumienia Junikowskiego wraz z rozlewiskami i dopływami, a Samicy Stęszewskiej poniżej Krąplewa sięga 3-4 km). Można więc domyślać się, że wprawdzie na krótsze dystanse użytkowano trakty biegnące w pobliżu większych dolin, to przy szlakach o dłuższym zasięgu wybierano rejony wyżej położone, charakteryzujące się mniejszą liczbą cieków i łagodniejszą rzeźbą terenu. Także w tej strefie rozmieszczone są osady, które ułatwiały znacząco pieszą wędrówkę - w ich sąsiedztwie znajdowały się przecież odlesione pola i pastwiska. Nie bez znaczenia była możliwość skorzystania z gościny u mieszkańców zobligowanych prawem do jej udzielenia.

Jako szczególnie ważny rejon w komunikacji pomiędzy terenami położonymi na wschód i zachód od Poznańskiego Przełomu Warty można wskazać okolice dzisiejszego Poznania. Uchodzące tu Cybina i Główna łączyły z Wartą najintensywniej zasiedlone rejony Pojezierza Gnieźnieńskiego, a jednocześnie, po przekroczeniu tej rzeki, kierowały ku skupiskom osadniczym położonym po jej zachodniej stronie. Początek rekonstruowanego traktu o ponadregionalnym charakterze (w ramach interesującego nas obszaru) należałoby więc lokować w okolicach ujścia Cybiny i Głównej (lub szerzej - od Jeziora Glinowieckiego po Koplę) i położonych tu licznych osiedli. Uwzględniając rozmieszczenie stanowisk, można go prowadzić w kierunku zachodnim wzdłuż górnych odcinków Strumienia Junikowskiego, Skórzynki i dalej przez skupisko osadnicze nad Wirynką (stanowiska w Dąbrówce). Dalszą podróż warunkowała możliwość przekroczenia linii Samicy Stęszewskiej i Samy. W pierwszym przypadku decydował rozkład brodów, które znajdowały się w rejonie Krąplewa, gdzie rozmieszczenie kęp w dolinie wyraźnie skracało trudny do przebycia odcinek drogi oraz na odcinku pomiędzy Jeziorem Tomickim a Niepruszewskim. W obu przypadkach szlak, zarówno w wariancie wodnym, jak i lądowym, prowadził ku dolnej Mogilnicy i tamtejszym osadom związanym z osadnictwem nadobrzańskim. Kolejne dogodne przejście znajdowało się pomiędzy Jeziorem Niepruszewskim a źródłami Samy (w przypadku szlaku wodnego możemy domyślać się w tym rejonie przewłoki łączącej obie rzeki), choć brak osadnictwa w tym rejonie może wskazywać na młodszą metrykę tego traktu, który prowadził na zachód przez Równinę Opalenicką ku osadom położonym pomiędzy źródłami Mogilnicy i Czarnej Wody, i dalej w rejon ujścia Obry do Warty. Zachodni odcinek, jak przypuszczamy, pozostawał wspólny dla dwóch szlaków omówionego wyżej, umownie nazwijmy go „południowym”, oraz „północnego”, którego początki można wyznaczać w rejonie skupisk położonych między Bogdanką a Rowem Północnym. Ten wiódł przez osiedla rozmieszczone powyżej Jeziora Kierskiego, przez dogodne przejścia na Samicy Kierskiej i Pamiątkowskiej, a dalej przez Samę - być może powyżej Jeziora Lusowskiego. Stosunkowo liczne osady w północnej części Pojezierza Międzychodzko-Sierakowskiego mogą sugerować, że szlak „północny” rozwidlał się po zachodniej stronie Samy i prowadził także 
w tamtym kierunku (prawdopodobnie można wiązać z nim osady nad Jeziorem Bytyńskim).

Uformowane w najstarszych fazach wczesnego średniowiecza skupiska osadnicze i łącząca je sieć komunikacyjna nie tylko nie uległy zmianie, ale zostały uzupełnione kolejnymi osiedlami. Co istotne, na przełomie fazy $\mathrm{B}$ i $\mathrm{C}$ nowe stanowiska pojawiają się poza nakreślonymi wyżej ramami tylko w rejonach łączących istniejące już struktury osadnicze. Szczególnie widoczne jest to w obrębie Równiny Opalenickiej i w okolicach Lwówka i Pniew. Znaczącej intensyfikacji uległo więc osadnictwo w pasie równoleżnikowym, pomiędzy silnie okupowaną strefą w rejonie dzisiejszego Poznania i Lubonia a dolnym odcinkiem Obry. Specyficznym wyrazem dokonującej się krystalizacji sieci osadniczej były ośrodki grodowe, które dość gęstą siecią pokryły szczególnie wschodnią i północną część terytoriów położonych między Wartą a Obrą. Możemy się domyślać, że etap budowy grodów poprzedziły osiedla warowne, a przynajmniej wydzielone z otaczającej przestrzeni rowami lub innymi urządzeniami (nasypami, palisadami itp.). Wprawdzie z omawianego terenu znamy zaledwie jeden taki przypadek, pochodzący z Dąbrówki, jednak podobne rozwiązania znane z ziemi lubuskiej, chełmińsko-dobrzyńskiej czy centralnej Polski (Tabaka, Zamelska-Monczak 2011; Kowalewski 1997; Góra 2004) pozwalają domyślać się podobnych odkryć także na innych wielkopolskich stanowiskach.

Wszystkie grody położone między Wartą a Samą/Samicą Stęszewską oraz w rejonie dolnej oraz górnej Mogilnicy i Czarnej Wody powstały w miejscach o strategicznym znaczeniu z punku widzenia połączeń komunikacyjnych, których ważną cechą był duży przepływ ludzi, informacji i dóbr. W kilku przypadkach jesteśmy w stanie potwierdzić, że ich powstanie poprzedziły rozległe osiedla, których „sukces" możliwy był dzięki dogodnemu położeniu, z drugiej zaś strony one same stymulowały rozwój sieci osadniczej i szlaków łączących je z bliższymi i dalszymi ośrodkami. W sąsiedztwie grodów na Równinie Opalenickiej i wzdłuż dolnej Samy i Ostrorogi notowane są jedynie stanowiska datowane na przełom faz B i C (zatem o stosunkowo późnej metryce), i to w niewielkim zakresie, ale i w ich przypadku wyraźny jest związek między lokalizacją a przebiegiem szlaków komunikacyjnych łączących ośrodki uformowane już w starszych fazach wczesnego średniowiecza. Brzoza, Sędzinko, Młynkowo (Wilczyna), Bródki i Niewierz znajdują się na trakcie wiodącym na Pszczew, Międzyrzecz, i dalej - na ziemię lubuską i dolną Odrę. Przez Równinę Opalenicką jednocześnie wiódł szlak południkowy, wzdłuż Mogilnicy ku Obornickiej Dolinie Warty i tamtejszym warowniom. Obrzańskie „wrota” na ten szlak otwierały grody w Kamieńcu i Konojadzie ${ }^{11}$ (ryc. 4:B, C,

11 Grodzisko zupełnie zostało zniwelowane i nie udało się potwierdzić jego lokalizacji w trakcie badań prowadzonych przez Zofię Kurnatowską i Alicję Łosińską. Położenie grodu zamieszczam na podstawie wyników prospekcji lotniczej przeprowadzonej w 2020 roku przez Marcina Krzepkowskiego, któremu dziękuję za udostępnienie informacji i zdjęć. 

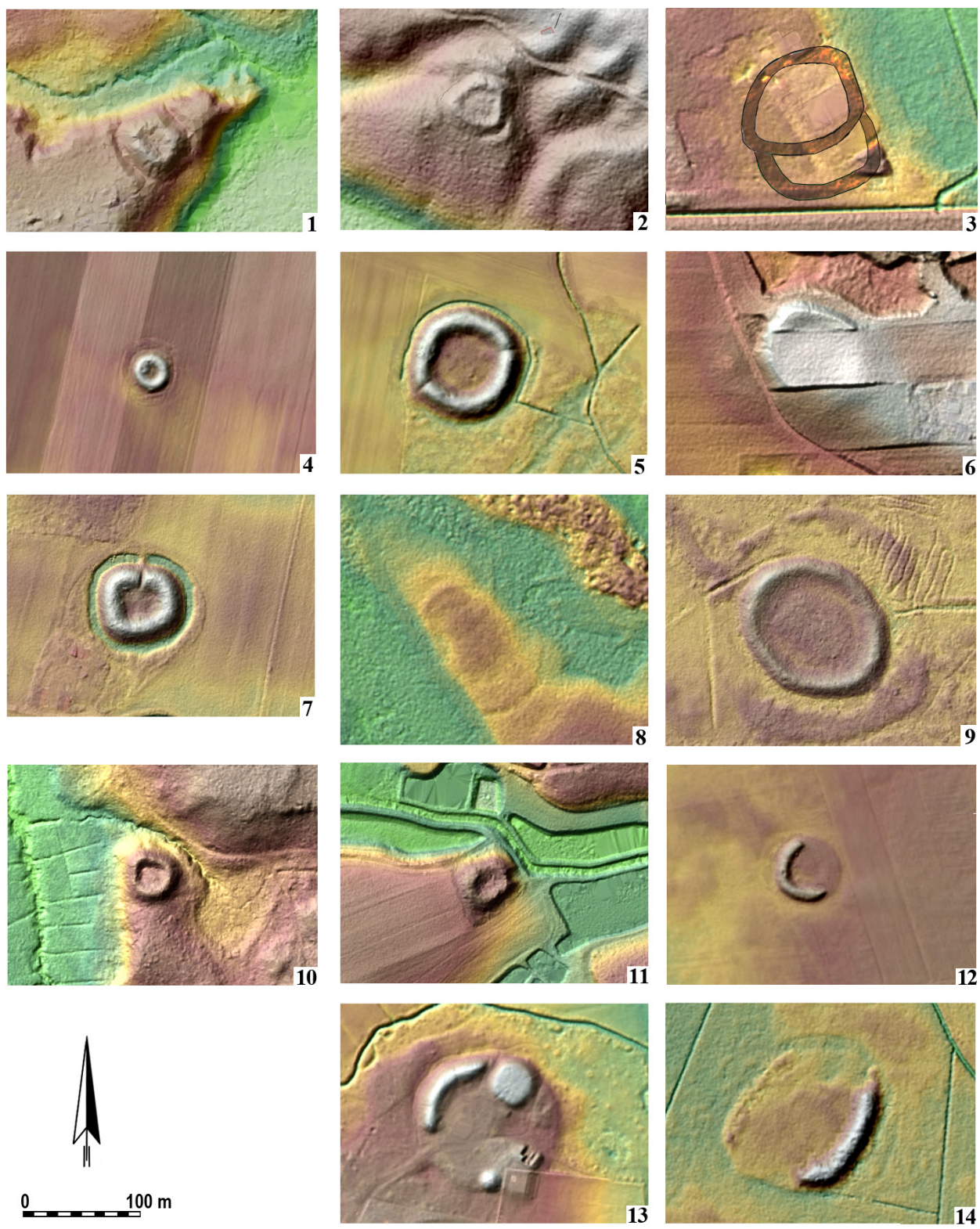

Ryc. 7. Numeryczne modele terenu wybranych grodzisk położonych na zachód od poznańskiego Przełomu Warty:

1 - Glinno, gm. Suchy Las; 2 - Nowa Wieś-Krąplewo, gm. Stęszew; 3 - Dąbrówka, gm. Dopiewo; 4 - Bródki, gm. Lwówek; 5 - Sędzinko, gm. Duszniki; 6 - Brzoza, gm. Duszniki; 7 - Jastrowo-Ostrolesie, gm. Szamotuły; 8 - Kąsinowo, gm. Szamotuły; 9 - Rudki, gm. Ostroróg; 10 - Nojewo, gm. Pniewy; 11 - Ryżyn, gm. Chrzypsko Wielkie; 12 - Komorowo, gm. Lwówek; 13 - Kamieniec, gm. loco; 14 - Dakowy Mokre, gm. Opalenica. Oprac. E. Pawlak na podstawie www.geoportal.pl 

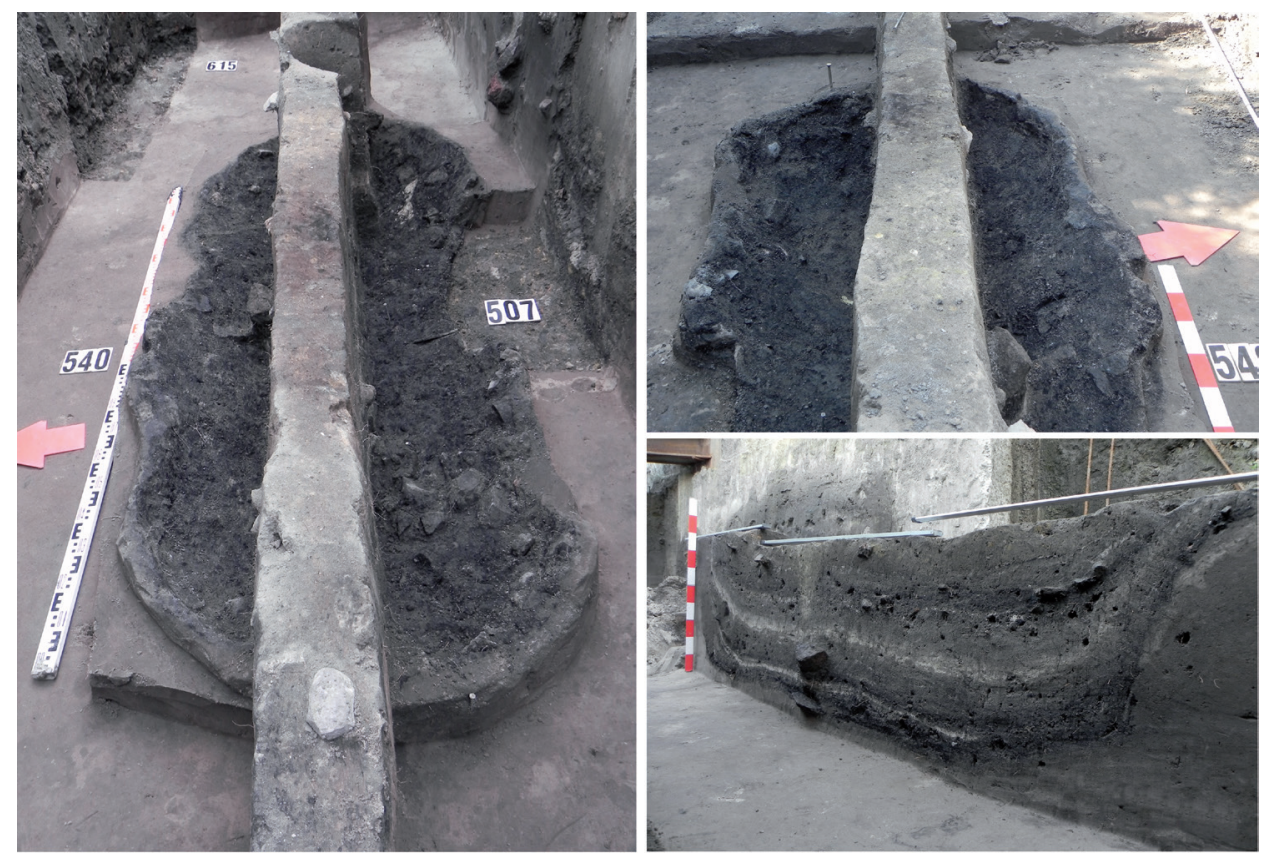

Ryc. 8. Relikty dłubanki z Poznania-Śródki. Fot. P. Pawlak

7:13), położone nad płynącymi niemal równolegle rzekami: Mogilnicą i Kanałem Grabarskim.

Szczególną uwagę, w kontekście bliskich związków między grodami a siecią komunikacyjną, zwraca opis warowni w Pawłowicach, w którym dość ogólnie jedynie wspomina się o pozostałościach drewnianej konstrukcji, określonej jako „palafit” (Hensel i Hilczer-Kurnatowska 19980, s. 37). Wziąwszy poprawkę na XIX-wieczny stan wiedzy, należy mieć na uwadze, że pale, które zarejestrowano w sąsiedztwie wałów (odsłonięte zapewne na etapie osuszania jeziora [Słownik... 1886, s. 910]), mogły stanowić pozostałość nabrzeża, mostu lub podobnej konstrukcji, ułatwiających przedostanie się z wody na ląd. Funkcjonowanie tego rodzaju urządzeń w pobliżu miejsc pełniących funkcje centrów gospodarczych, religijnych i politycznych, jakimi były grody, wydaje się wręcz nieodzownym elementem.

Obserwując „fizyczne” cechy tutejszych grodów, można zauważyć ciekawą prawidłowość - poza kilkoma przypadkami mamy do czynienia z obiektami o czworo- lub pięciobocznym zarysie wałów (ryc. 7). Wyjątek od tej reguły stanowią grody w Bródkach, w dolinie Mogilnicy oraz w Kamieńcu i Konojadzie, które jednak należy łączyć z osadnictwem nadobrzańskim, wykazującym silne związki ze strefą Tornow-Klenica. Niejednoznacznie prezentują się pozostałości obwałowań 
Sędzinka - wydaje się, że ich w przybliżeniu kolisty zarys może być efektem erozji nasypów, natomiast pierwotnie zbliżony był do czworobocznego. Trudne do określenia są obiekty zachowane we fragmencie lub zniwelowane w całości: w Komorowie, położonym nad Czarną Wodą oraz Kąsinowie nad Samą i Pawłowicach ${ }^{12}$ nad Samicą Kierską. Zwraca uwagę rozmieszczenie największych obiektów, o maksymalnych rozmiarach sięgających 100-140 m - do linii wyznaczonej przez Samę/ Samicę są to Pawłowice (średn. około $100 \mathrm{~m})$ i Dąbrówka $(120 \times 85 \mathrm{~m})$, które są położone na początkowym odcinku traktów wiodących od Poznańskiego Przełomu Warty oraz Kąsinowo (około $100 \times$ ? m), które ulokowane na szlaku wodnym „otwiera” ten rejon na równoleżnikową dolinę Warty. Kluczowe miejsce na zachód od przejścia pomiędzy Samą a Samicą, w odległości niespełna $4 \mathrm{~km}$ od niego, zajmuje Brzoza (około $100 \times 80 \mathrm{~m}$ ), a położone $7 \mathrm{~km}$ dalej na zachód Sędzinko (około $95 \times 95 \mathrm{~m}$ ) łączy trakt równoleżnikowy z południkowym, wiodącym doliną Mogilnicy. Podobne uwarunkowania odnoszą się do obiektu w Dakowach Mokrych (około $135 \times 115 \mathrm{~m}$ ) - być może tę lokalizację należy rozpatrywać w kontekście domniemanego grodu w rejonie Grodziska Wielkopolskiego i starszych osad w Kotowie, Strzępiniu i Snowidowie i wyznaczać na ich podstawie trakt, który utrzymał się po czasy współczesne. Ciekawie prezentuje się również grodzisko w Rudkach, największe spośród wszystkich warowni tego regionu (rozpiętość jego wałów wynosi $140 \times 120 \mathrm{~m}$ ), położone nad niewielkim dopływem Samy, który trudno uznać za pełniący istotniejszą funkcję komunikacyjną. Zalesienie tego rejonu uniemożliwia ocenę zaplecza osadniczego, które mogłoby uzasadnić powstanie tak dużego obiektu. Rudki, wraz z sąsiednim, znacznie mniejszym i być może młodszym Jastrowiem-Ostrolesiem (Pietrzak 2003, s. 71) zajmują teren wysoczyzny i są odgrodzone od strefy doliny pasem moren - być może więc należy w tym rejonie doszukiwać się skupiska osadniczego położonego w strefie dogodniejszej do zamieszkania, przez które prowadził szlak lądowy wprost ku licznym osiedlom rozmieszczonym w dolinie Warty poniżej Sierakowa. Rzut oka na mapę pozwala więc odnieść wszystkie największe grody do kluczowych odcinków traktów lądowych lub wodno-lądowych o dalekim zasięgu, wiodących od Poznańskiego Przełomu Warty na zachód: południowym - rozdzielającym się w okolicy grodu w Dąbrówce na Dakowy Mokre (dolną Mogilnicę) i Brzozę (Równina Opalenicka) oraz północnym - przez Pawłowice, Kąsinowo i Rudki (północna część Pojezierza Poznańskiego). Prowadziły one ku południowej Wielkopolsce, Śląskowi, Łużycom na ziemię lubuską, Pomorze i Połabie, w kierunku wschodnim zaś ku ziemi gnieźnieńskiej.

Grody w Dąbrówce, Brzozie i Rudkach łączy jeszcze jeden charakterystyczny element - wszystkie obwiedziono wałami na planie wydłużonego pięcioboku (ryc. 9:3, 6, 9). Najwyraźniej kształt ten jest widoczny w Dąbrówce i Brzozie,

12 Jego gabaryty oraz schematycznie przedstawiony zarys znane są jedynie z przekazów archiwalnych (Feldmanowski 1877; Hensel i Kurnatowska 1980). 

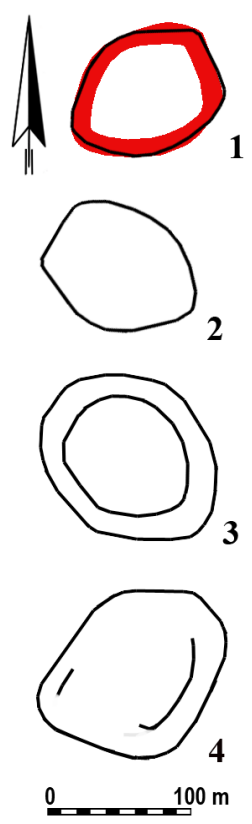

Ryc. 9. Zarysy umocnień grodów: w Dąbrówce (1) z nałożonym przeorientowanym zarysem grodu w Brzozie, (2) Brzozie, (3) Rudkach i (4) Dakowach Mokrych. Oprac. E. Pawlak

w których zniwelowane lub szczątkowo zachowane wały pozwalają na jednoznaczne wykreślenie zarysu umocnień na podstawie ich zachowanej wziemnej części ${ }^{13}$. Co ciekawe, oba te grody łączy bliźniacze podobieństwo - rekonstruowany na podstawie fotografii lotniczych i map lidarowych zarys wałów w Brzozie po przeorientowaniu względem kierunków świata pokrywa się z tym, który na podstawie badań wykopaliskowych i fotografii zrekonstruowano dla Dąbrówki (ryc. 9). W przypadku Rudek osypujące się przez kilka stuleci drewniano-ziemne konstrukcje doprowadziły do zniekształceń, pozwalając jednak na identyfikację sposobu rozplanowania umocnień. Również pięcioboczny zarys mają pozostałości grodu w Dakowach Mokrych, jednak odmienne proporcje raczej wyłączają go z omówionej grupy. Jeśli przyjmiemy, że gród wyznaczał dla użytkujących go społeczności swoisty obraz świata, lokalny kosmos, to tak istotny element jak jego forma nie mógł być dziełem przypadku, ale urzeczywistnieniem ogólniejszej wizji odnoszącej się także do kwestii pozautylitarnych. Nie rozstrzygniemy kwestii, czy zbliżone,

13 Metodę stabilizacji wałów polegającą na umieszczaniu najniższych warstw w rowie (stanowiącym rodzaj fundamentowania) spotykamy także po wschodniej stronie Warty - podobne rozwiązania zastosowano np. w najstarszym grodzie wzniesionym na Ostrowie Lednickim (Kara i Wrzesiński 2016 s, 85 i nn.). 
lub nawet identyczne rozplanowanie umocnień można traktować jako wyraz wspólnej dla mieszkańców tych terenów wizji dotyczącej budowy podobnych obiektów, czy jest ono efektem bezpośredniej współpracy pomiędzy poszczególnymi jednostkami terytorialnymi, czy też może zapożyczeniem z odleglejszych terytoriów, zastosowanym na rodzimym gruncie $\mathrm{w}$ różnych wariantach?

Niestety, nie dysponujemy wiedzą, w jakim stopniu wymienione ośrodki były użytkowane jednocześnie, choć z punku widzenia ich związku z siecią komunikacyjną ma to drugorzędne znaczenie. Nie wiemy też, jak długo je użytkowano, jaki był zasięg towarzyszących im osiedli, czy ich większe rozmiary łączyły się z uprzywilejowaną pozycją wobec wspólnot użytkujących mniejsze grody, czy też raczej są efektem specjalnej roli, jaką pełniły w ramach całej organizacji terytorialnej, której istnienia domyślamy się po zachodniej stronie Warty. Pewien wgląd w tę sytuację umożliwiły badania prowadzone w Dąbrówce - czas funkcjonowania tamtejszego grodu musiał być na tyle długi, że przynajmniej raz przebudowano majdan, dość gruntownie zmieniając sposób jego zagospodarowania, a sam gród powiększono o stosunkowo rozległe podgrodzie (około $70 \times 25 \mathrm{~m}$ ) otoczone wałem. Warowne centrum otoczone było rozległą osadą, otoczoną przynajmniej w początkowym etapie istnienia rowem i być może innymi urządzeniami limitującymi zamieszkaną przestrzeń. Prócz najbliższego zaplecza zajmującego powierzchnię 6 hektarów, w sąsiedztwie grodu funkcjonowały mniejsze osady, tworząc wraz z nim rozległy kompleks (Pawlak i Pawlak 2019, s. 109 i nn., s. 147-154, ryc. 6.45). O ile można wnosić z odkrytych materiałów i kontekstu historycznego, schyłek funkcjonowania warowni przypada na czas nie późniejszy niż 2. i początek 3. ćwierci $X$ wieku, i łączyć go można z przejmowaniem przez Piastów terenów położonych na zachód od Poznańskiego Przełomu Warty. Pewne przypuszczenia można wysnuwać także w odniesieniu do Kąsinowa i Brzozy na podstawie wyróżników roślinnych obserwowanych na ich powierzchni. W pierwszym przypadku zwielokrotniony zarys wschodniej części wału pozwala domyślać się podgrodzia, w drugim - widoczna jest raczej jednofazowa, a przynajmniej skromniejsza niż w Dąbrówce zabudowa majdanu, choć ten element nie do końca stanowi przesłankę mówiącą o długotrwałości użytkowania.

Zwiększająca się intensywność kontaktów interregionalnych czytelna jest w materiałach ruchomych pozyskiwanych na stanowiskach datowanych na okres od schyłku VIII wieku. Szczególnie dobrze obecność zewnętrznych impulsów kulturowych można obserwować w ceramice - jedynej dostępnej badaniom grupie przedmiotów codziennego użytku. Ilustruje ona dość wiarygodnie zmieniającą się stylistykę, a jednocześnie pozwala wychwycić w zespołach materiały pochodzące spoza lokalnych warsztatów. Najliczniejszy i dość zróżnicowany zbiór pochodzi z grodziska w Dąbrówce - wydzielono w jego ramach kilka grup naczyń 

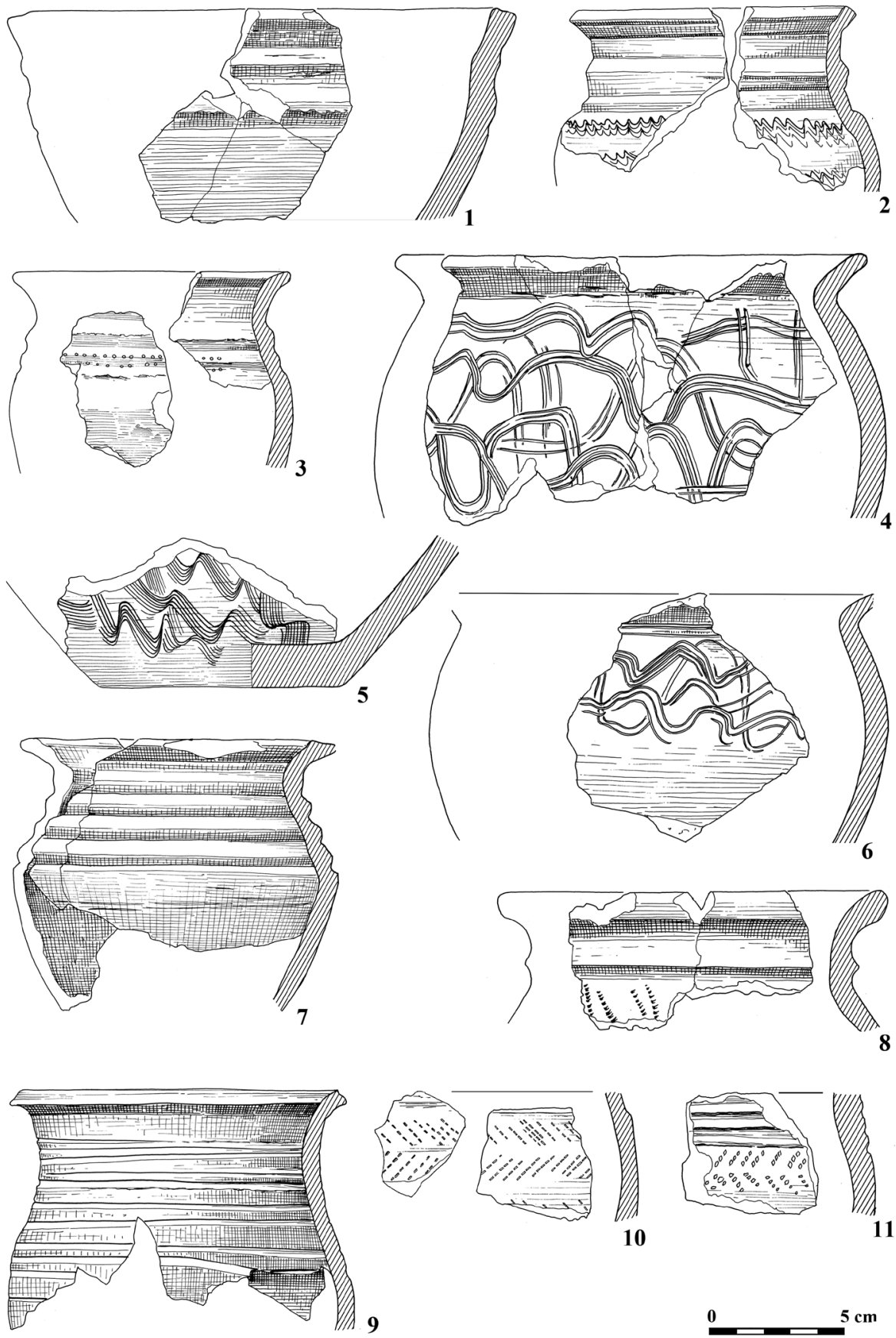

Ryc. 10. Dąbrówka, gm. Dopiewo - wybór fragmentów naczyń z osady poprzedzającej powstanie grodu i z zabudowy grodu na stan. 2. Rys. E. Pawlak 

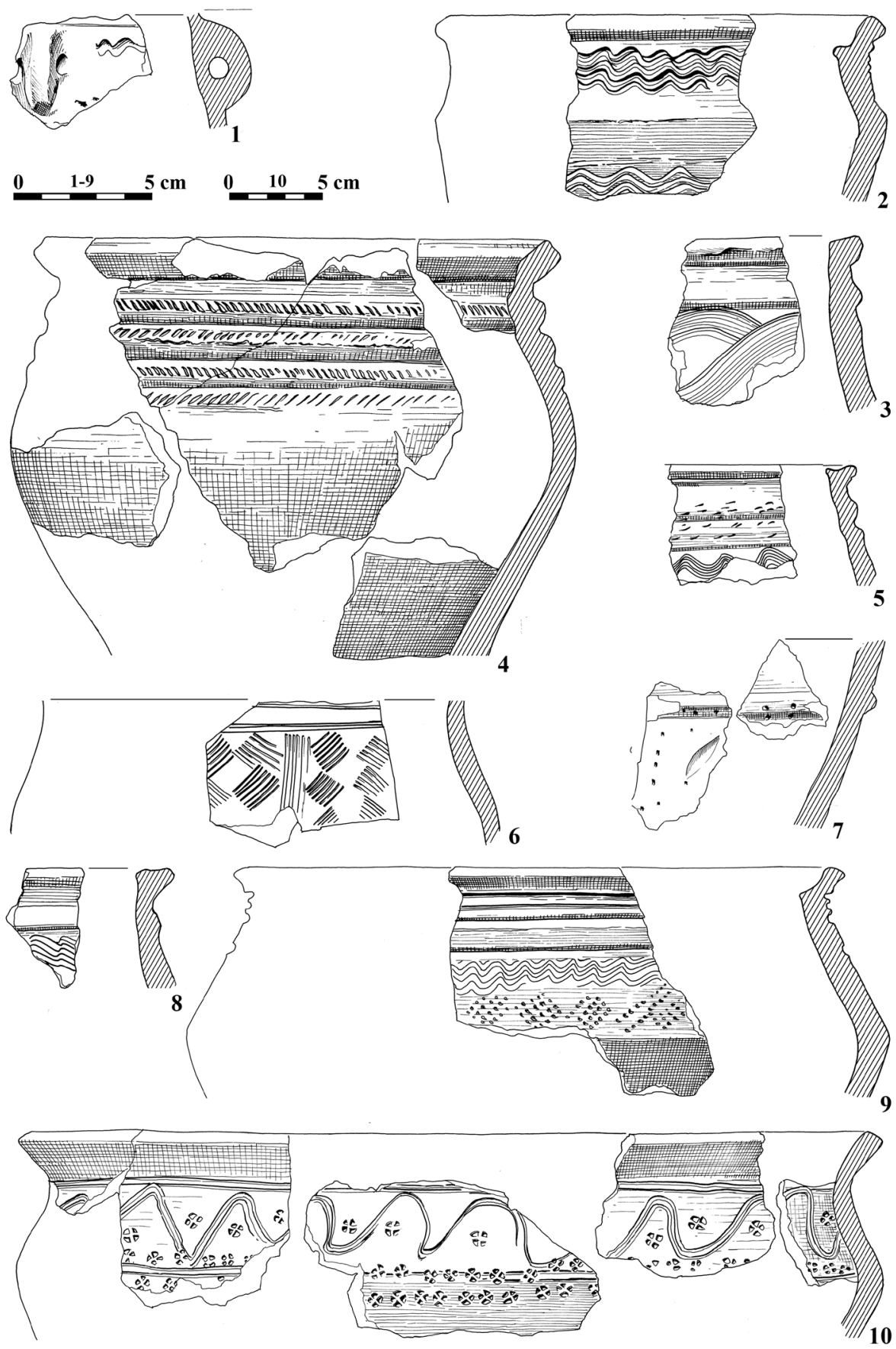

Ryc. 11. Dąbrówka, gm. Dopiewo - wybór fragmentów naczyń z osady na stan. 1 (1) i zabudowy grodu na stan. 2 (2-10). Rys. E. Pawlak 

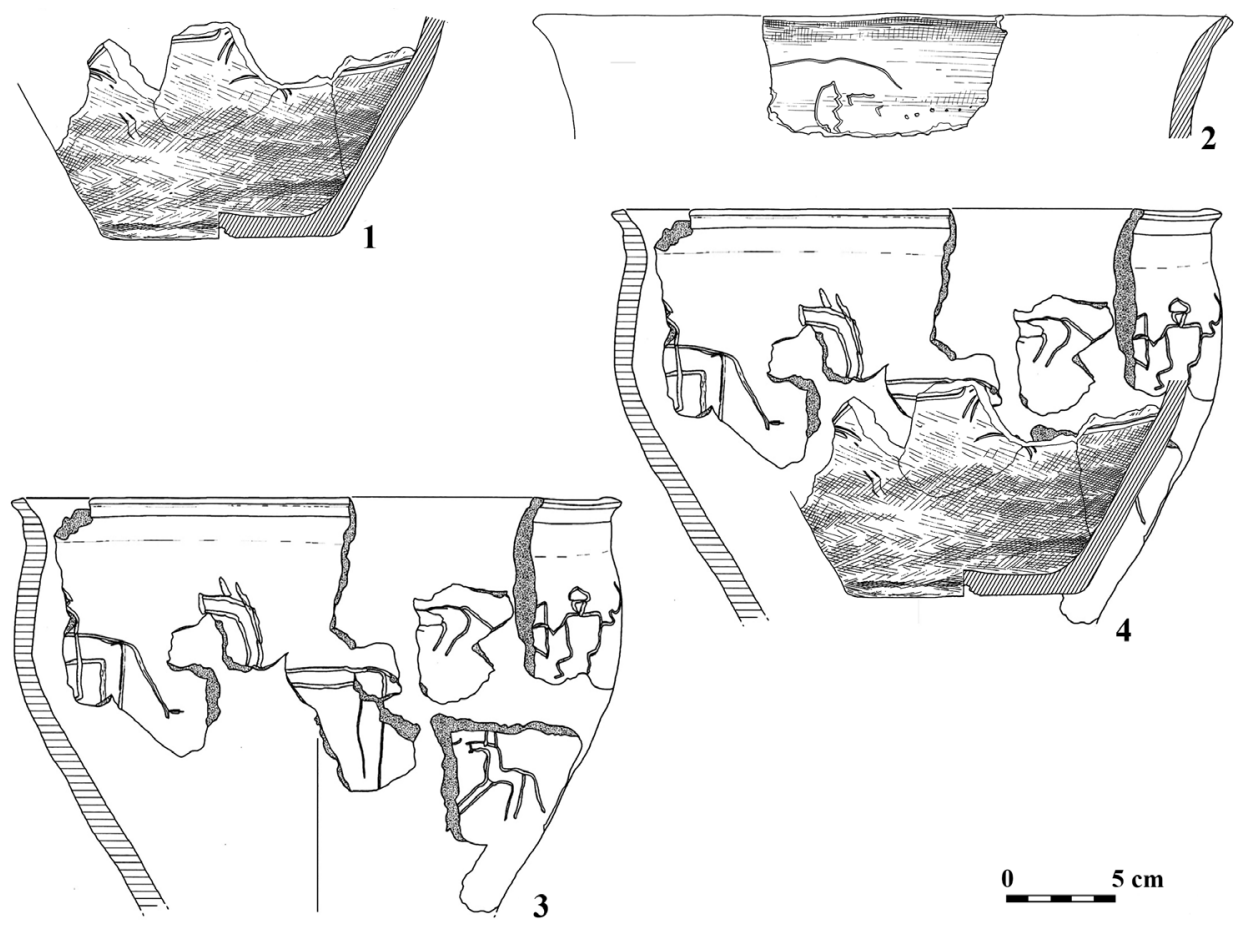

Ryc. 12. Fragmenty naczyń z dekoracjami figuralnymi z grodziska w Dąbrówce, gm. Dopiewo (1-2), naczynie z grodziska w Repten, kr. Calau (4; wg Messal 2011, ryc. 14:7), nałożone naczynia z Dąbrówki i Repten (4)

wykonanych w stylistyce: Gołańcz $(82,93 \%)^{14}$, Tornow $(4,89 \%)$, Menkendorf $(3,4 \%)$, Feldberg (2,65\%), Gołańcz/Menkendorf (1,57\%), Gołańcz/Feldberg $(0,25 \%)$, Woldegk $(0,5 \%)$ oraz pojedyncze okazy w typie Bruszczewo, Glienke i grupy dalkowsko-obrzańskiej (ryc. 10, 11; Pawlak i Pawlak 2019, s. 251-266). $\mathrm{Na}$ podstawie przedstawionego zestawienia rysuje się obraz miejscowego garncarstwa (a jak możemy się domyślać, także innych dziedzin wytwórczości, których ślady nie przetrwały), podlegającego wpływom warsztatów północno-zachodniosłowiańskich i w mniejszym zakresie płynącym ze strefy Tornow-Klenica, odnoszonej do Łużyc, dorzecza środkowej Odry i południowej Wielkopolski. Także w odniesieniu do naczyń zaliczonych do typu Feldberg i Woldegk autorzy opracowania ceramiki przyjęli, że jakość przynajmniej niektórych egzemplarzy pozostawała poza możliwościami uzyskania w miejscowych warsztatach garncarskich, zatem ich pochodzenia należy upatrywać na Pomorzu lub Połabszczyźnie. Szczególny przypa-

${ }^{14} \mathrm{~W}$ opracowaniu ceramiki nawiązano do nomenklatury stworzonej przez W. Łosińskiego dla ceramiki pomorskiej, rezygnując z systematyki wypracowanej dla Wielkopolski przez Z. Hilczerównę ze względu na to, że ilustruje ona pełniej zespół cech występujących w materiałach z Dąbrówki. 
dek stanowi dolna część naczynia pokrytego dekoracją figuralną (ryc. 12), do którego bezpośrednią analogię stanowi zrekonstruowany w dużym zakresie egzemplarz z Repten - łużyckiego grodziska położonego nad Sprewą. Pomijając zupełnie kwestię, w którym ośrodku zostały wytworzone te naczynia zdobione $\mathrm{z}$ dużym prawdopodobieństwem jedną ręką, mogą one wskazywać na bezpośrednie kontakty pomiędzy obydwoma rejonami. Warto w tym miejscu odnieść się do materiałów ceramicznych pochodzących z grodzisk w Santoku i Międzyrzeczu, w których proporcje pomiędzy poszczególnymi typami naczyń (Menkendorf, Feldberg, Woldegk i Tornow) wskazują na związek obu tych grodów odpowiednio ze strefą wielecko -pomorską oraz południowo-zachodnią, utożsamianą z silnymi wpływami z kręgu Tornow-Klenica (Zamelska-Monczak 2008, s. 219). Można więc przyjąć, że zasięg wpływów strefy nadbałtyckiej był znacznie większy, niż to zakładano, i sięgał po terytoria położone po południowej stronie dolnej Warty, aż po jej południkowy odcinek w rejonie dzisiejszego Poznania.

Wyjątkowo możliwe jest uchwycenie zewnętrznych wpływów kulturowych w sferze niematerialnej, odnoszącej się do organizacji przestrzeni zamieszkanej, jak możemy się domyślać związanej także ze zmianami społecznymi. Jedynym znanym nam dotąd przykładem takiego zjawiska jest zmiana sposobu zabudowy wnętrza grodu w Dąbrówce. W pierwszej fazie użytkowania tego obiektu, równolegle do północnej części umocnień wzniesiono pojedynczy szereg domostw, które otaczały centralny plac; w fazie drugiej, równolegle do dłuższej osi grodu powstało kilka szeregów budynków, tworzących regularną zabudowę wschodniej części majdanu. Analogie do tego rodzaju szeregowego rozplanowania znajdujemy na grodach typu felberskiego (Łosiński, 2008, s. 83-84). Źródeł inspiracji dla zabudowy użytkowanej w młodszej fazie należy więc upatrywać w strefie północno-zachodniosłowiańskiej.

Po zlikwidowaniu przez Piastów sieci grodowej na zachód od południkowego biegu Warty i - jak możemy się domyślać - towarzyszącym temu procesowi przemieszczeniom ludności, zmiany musiały także objąć sieć komunikacyjną. Wprawdzie zniszczeniu uległy same grody, a nawet niekiedy wyrosłe w ich sąsiedztwie osiedla, jednak w miejsce dawnych ośrodków władzy musiały powstać inne, w których nowi włodarze przez swych reprezentantów zarządzali zaanektowanymi terytoriami. Być może potwierdzeniem takiego właśnie przeniesienia przynajmniej części kompetencji na nowy ośrodek (w zakresie odpowiadającym panującym) są osady odkryte w Głuchowie, odległym od grodziska w Dąbrówce o zaledwie $3 \mathrm{~km}$. Starsza osada, wchodząca w skład organizacji terytorialnej związanej z tym grodem, po jego likwidacji zapewne jeszcze przed połową $X$ wieku przeżyła rozkwit, a odkryte w tamtejszych obiektach przedmioty o luksusowym charakterze wskazują na użytkowników o wysokim statusie materialnym. W warunkach podbitego terytorium musiały być to osoby związane $\mathrm{z}$ nową władzą, niezależnie od tego, czy wywodziły się ze środowiska lokalnego, czy też zewnętrznego. Wśród owych przedmiotów znajdują się bogato dekorowane grzebienie z poroża łączone z pracowniami pomorskimi, kabłączek typu pomorskiego, okucie pochewki noża, czy 

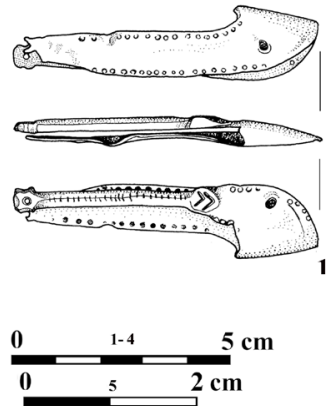

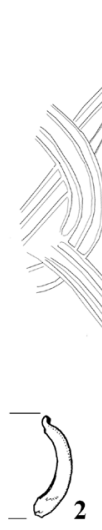

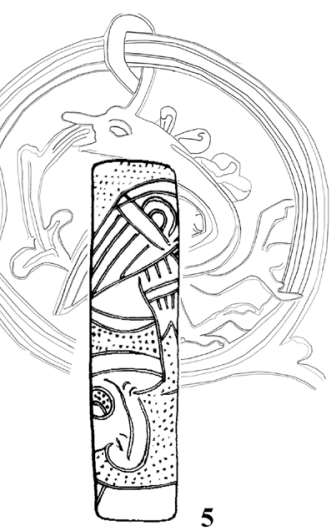
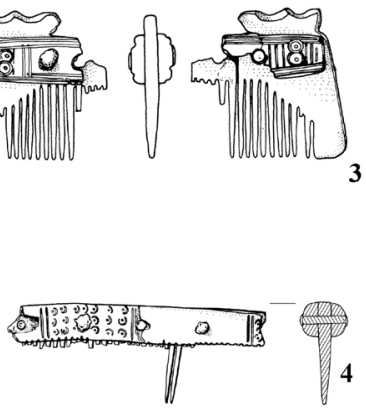

Ryc. 13. Wybór zabytków z osady w Głuchowie, stan. 145 (rys. M. Żółkiewski, oprac. E. Pawlak)

wreszcie fragment brązowej (złoconej?) płytki z wyobrażeniem ptaka, analogicznej do egzemplarza pochodzącego z Perkowa, gm. Przemęt (ryc. 13; Hensel 1980:44, ryc. 1). Zarówno odkryte przedmioty, jak i kontekst osadniczy i topograficzny pozwalają umieszczać Głuchowo na trakcie komunikacyjnym o dalekim zasięgu, który po likwidacji grodu przesunął się nieznacznie na południe, niezmiennie jednak łączył Wartę, a wówczas już warownię na Ostrowie Tumskim, z brodami na Samicy Stęszewskiej. Można więc przypuszczać, że w Głuchowie ulokowano nie tylko „,punkt kontroli” szlaku handlowego, ale również siedzibę osób, którym powierzono zarządzanie dawnym opolem, choćby w zakresie sprawowania kontroli realizacji zobowiązań wobec panujących.

Zbliżoną sytuację obserwujemy w nieodległym Krąplewie - także tutaj upadek grodu przełożył się na likwidację funkcjonujących w jego pobliżu osad. Położone tu brody na Samicy wymuszały jednak zachowanie dawnego traktu w jego dotychczasowej formie - tędy wiodło bowiem połączenie z Poznania w kierunku południowej Wielkopolski i Śląska, wykorzystujące najwęższy odcinek Obry, który między Kościanem a Czempiniem wynosi zaledwie 1,3-2 km. W dobie plemiennej, w strefie obrzańskiej były tu rozlokowane grody w Kościanie-Kurzej Górze, Bonikowie i Starym Tarnowie i nawet jeśli zostały zlikwidowane (niezależnie od czasu, kiedy to się dokonało), to warunki topograficzne nie uległy przecież zmianie. Być może więc słusznie Gerard Labuda rekonstruował przebieg pielgrzymki Ottona III właśnie przez Wschowę i Kościan (Labuda 1988, s. 504) ${ }^{15}$. Przejście

${ }^{15}$ Z. Kurnatowska wskazywała, że po opuszczeniu Głogowa trasa pielgrzymki kierowała się na Śrem, „gdyż szlak lewobrzeżny z Poznania przez Kościan na Śląsk powstał dopiero po lokacji Poznania w XIII w., a w Kościanie i Wschowie nie było grodów wczesnopiastowskich i nawet osadnictwo otwarte z tego czasu jest w tych partiach Wielkopolski południowej dość słabe" (Kurnatowska 2002, s. 95). Abstrahując od drogi obranej przez Ottona III, szlak wiodący do Poznania z południowej Wielkopolski miał znacznie starsze tradycje - nie sposób nie zauważyć położenia grodu w Bonikowie, 
przez Samicę w okolicach Krąplewa funkcjonowało także w kolejnych stuleciach korzystne warunki doprowadziły do powstania w rejonie brodów w XII-XIII wieku nowej, niezwykle rozległej osady o charakterze służebnym, zajmującej obydwa stoki doliny. Trakt ten, do którego nawiązywały lokalne drogi widoczne jeszcze na mapach z XIX wieku, uległ zmianie zapewne dopiero w młodszych fazach średniowiecza, kiedy to gwałtownie zmieniające się stosunki własnościowe doprowadziły do zmiany nie tylko sieci osadniczej, ale i związanej z nią ściśle sieci drożnej.

Naturalne warunki sprzyjały także utrzymaniu szlaku wiodącego niegdyś od Poznańskiego Przełomu Warty na zachód, przez grody w Brzozie i Sędzinku organizację komunikacji w tej strefie narzucała możliwość przejścia suchą stopą między Samą a Samicą Stęszewską. Na nim właśnie swą „karierę” zbudował Buk, włączony w 1. połowie XIII wieku w szlak handlowy o znacznie szerszym zasięgu, który wiódł z Halle, przez Gubin, Krosno, Zbąszyń do Poznania, zmierzając dalej ku Państwu Krzyżackiemu (Przybył 2005, s. 119). Wydaje się, że tędy także mogła przebiegać trasa wyprawy, którą w 1005 roku Henryk II prowadził przeciw Bolesławowi Chrobremu. Wyruszywszy z Międzyrzecza, korzystając ze szlaków prowadzących przez skupiska osadnicze w rejonie Pniew i Lwówka, mógł łatwo dotrzeć do upragnionego celu prostą drogą bez pokonywania większych rzek. Trasa ta zapewniała stałą aprowizację, rozmieszczone tu osady dostarczały bowiem pożywienia dla ludzi i zwierząt, a zapewne także noclegu. Rozwiązanie to wydaje się korzystniejsze od trasy zaproponowanej przez Macieja Przybyła (2005, s. 115), w której aby dotrzeć do Poznania przez Kaźmierz, Komorowo, Krzyszkowo, Kiekrz i Sołacz, wojsko kolejno musiałoby pokonać Samę, Samicę Pamiątkowską i Kierską ${ }^{16}$. Zważywszy na to, że wojsku towarzyszyły duże ilości podwód (Dąbrowski 1998 s. 252), trasa musiała sprawiać jak najmniej kłopotów, których trudno było uniknąć, pokonując liczne przeszkody wodne. Pokój zawarty w 1157 roku w Krzyszkowie, w kontekście informacji, że wojsko Fryderyka Barbarossy podążało śladem poprzednich wypraw, może potwierdzać zaproponowany przez M. Przybyła wariant trasy. Pamiętać jednak należy o tym, że wycofujący się wówczas w stronę Poznania książęta zdecydowali o niszczeniu za sobą wszystkiego, co mogło się przydać nacierającej armii (Miśkiewicz 1991, s. 229 i nn.), a zniszczeń takich dokonywano $\mathrm{z}$ pewnością na trasie spodziewanego marszu. Nie możemy więc wykluczać, że w celu zapewnienia aprowizacji Fryderyk wybrał drogę okrężną, informacja zaś o zbieżności przebiegu tej wyprawy z wyprawami z początków

a także sąsiedniej Kurzej Góry na szlaku wodnym prowadzącym z północy, przez dolinę Mogilnicy, na południe - wzdłuż Samicy (lewostronnego dopływu Obry), Kopanicy lub sąsiednich rzek ku Odrze w rejonie Głogowa. Można przyjąć, że właśnie tą drogą, lub jej lądowym wariantem przez Wysoczyznę Leszczyńską, napływały na tereny położone na północ od Obry i obecne w zbiorze z grodziska w Dąbrówce naczynia zaliczone do typu Bruszczewo, dalkowosko-obrzańskiej rodziny typów, lub nawiązujące do wytworów południowopolskich lub czeskich (Pawlak i Pawlak 2019c, s. 249, 266).

${ }_{16}$ Mniej kłopotliwa wydaje się także trasa przecinająca jedynie Samę powyżej Jeziora Lusowskiego, od którego wiodła już prosta droga na Poznań. 
XI wieku odnosi się do ich śląskiego i południowowielkopolskiego odcinka. Niezależnie, czy posuwające się ku Poznaniowi wojsko cesarskie podążało śladem wypraw Henryka II, obrany przez nią szlak miał metrykę przynajmniej IX-wieczną i łączył skupiska osadnicze, począwszy od Poznańskiego Przełomu Warty po okolice Sierakowa i Międzychodu.

Andrzej Wędzki, opisując strukturę terytorialną doby „plemiennej” na terenach położonych pomiędzy Poznańskim Przełomem Warty, doliną Obry oraz Wartą w dolnym biegu (do ujścia Obry), wskazał na jej rozproszony charakter, wykluczając, by znajdujące się tu grody świadczyły o obecności większych organizacji terytorialnych (Wędzki 1996, s. 70) w typie tych, które wyznacza się w dorzeczu Obry czy okolicach Gniezna. Podobną opinię wyrazili także Zofia i Stanisław Kurnatowscy, pisząc: „Dotychczas zaobserwowany obraz osadnictwa tego terenu, jak się wydaje, nie potwierdza przypuszczeń o możliwości istnienia wspomnianego 'poznańskiego zespołu osadniczego’ z centrum skupionym nad górną Mogilnicą, którego wschodnie rubieże miały sięgać na obszar współczesnego Poznania. [...] Wyniki badań [...] zdają się wskazywać, że nie mogło tam dojść do powstania zintegrowanego plemienia a jedynie wykształciło się kilka niewielkich wspólnot terytorialnych typu opolnego" (Kurnatowscy 1996, s. 70). O ile uwagi te można by odnieść do zachodniej części regionu, począwszy od doliny Mogilnicy, o tyle stan zasiedlenia części wschodniej, rysujący się na podstawie dotychczasowego stanu badań, uprawnia do wysunięcia przypuszczeń o bardziej zaawansowanej organizacji zamieszkujących tu społeczności. Zastrzeżenie musi także budzić określenie „poznański zespół osadniczy” - wprawdzie w rejonie dzisiejszego Poznania funkcjonowały pojedyncze osady już w najstarszych fazach wczesnego średniowiecza, których liczebność z czasem wzrastała, doprowadzając do powstania kilku skupisk rozciągających się po obu brzegach Warty na długości kilkunastu kilometrów, zamieszkujące tu wspólnoty nie wykształciły jednak większego ośrodka centralnego. Być może w dobie „plemiennej” taką funkcję dla osad położonych na północ od Bogdanki pełniła niewielka warownia nad Jeziorem Glinowieckim. Powstanie grodu na Ostrowie Tumskim przypada dopiero na 1-2 ćwierć X wieku, a więc na czas wielkich inwestycji grodowych łączonych $\mathrm{z}$ ekspansją państwa Piastów. Nie można zatem postrzegać stanu organizacji społecznej terenów położonych na zachód od Warty przez pryzmat zmian, które zaszły stosunkowo późno, nawet jeśli odcisnęły nieusuwalne piętno na późniejszych losach rozległych terytoriów Wielkopolski i później Polski.

Stosunkowo zwarty charakter najstarszej sieci osadniczej, a od IX wieku także grodowej, której swoiste osie wyznaczały południkowo biegnące szlaki wodne i równoleżnikowe trakty lądowe, wskazuje, że zamieszkujące tu społeczności tworzyły wspólnotę terytorialną. W publikacji poświęconej Dąbrówce autorzy napisali: „Być może wszystkie wymienione grody, przynajmniej na jakimś etapie, współpracowały ze sobą dla realizacji wspólnych, mniej lub bardziej doraźnych celów. Niekoniecznie więc właściwą drogą byłoby doszukiwanie się istnienia jakiegoś plemienia/plemion zamieszkującego te tereny, choć z pewnością wspólny 
język, zbliżony system wierzeń, normy zachowań, gospodarowania, warunki bytowania, zamieszkiwanie sąsiadujących ze sobą terytoriów i wynikające z tego liczne kontakty (handel, małżeństwa, być może współpraca polityczno-militarna i inne) sprzyjały wytworzeniu się więzi i poczuciu wspólnoty, przynajmniej w odniesieniu do świata zewnętrznego" (Pawlak i Pawlak 2019b, s. 664). Być może najlepszym określeniem charakteru tej organizacji byłaby „wspólnota interesów gospodarczych", którą na potrzeby opisu strefy przybałtyckiej stworzył Władysław Łosiński (2008, s, 144). Związek ten od wschodu opierałby się na Poznańskim Przełomie Warty, od zachodu na Samicy Stęszewskiej i Samie, wraz z ich dopływami. Należy podkreślić odrębność tych terytoriów od sąsiedniej południowej Wielkopolski i doliny Obry (ciążących ku strefie Tornow-Klenica i szeroko rozumianemu południowi: Śląskowi, Czechom i Morawom), widoczną w stylistyce ceramiki, formie wznoszonych tu grodów i wyraźnym braku zasiedlenia terenów „,przygranicznych”.

Prócz wymienionego obszaru, po zachodniej stronie Poznańskiego Przełomu Warty można wymienić jeszcze dwa skupiska osadnicze: lwówecko-pniewskie, położone w górnych odcinkach Mogilnicy i Czarnej Wody oraz w dolinie Warty poniżej Sierakowa, choć w obu tych przypadkach mamy do czynienia z niepomiernie mniejszymi organizacjami terytorialnymi. Nie ulega wątpliwości, że wszystkie grody położone na tych terenach nie funkcjonowały równocześnie - nikły stan rozpoznania sprawia jednak, że wydzielanie obiektów o starszej lub młodszej metryce mogłoby wprowadzić w błąd. Nie wiemy, w jakim stopniu poszczególne ośrodki były od siebie zależne, czy rozmiary grodów miały związek z wielkością użytkujących je społeczności i pełnionymi przez nie funkcjami, jednak struktura ta do 2. ćwierci X wieku pozostawała poza strefą identyfikowaną z najstarszym państwem Piastów. Przejęcie tego obszaru nastąpiło zapewne dopiero po włączeniu w jego obręb południkowego odcinka Warty i wzniesieniu grodu w Poznaniu. Tereny „Usque in Vurta fluvium” (Thietmar II, 19) weszły wówczas w skład rdzenia Mieszkowego państwa, nazywanego z czasem Wielką Polską.

\section{BIBLIOGRAFIA}

\section{Opracowania niepublikowane}

Cież O., Daraż W. 2010, Uwarunkowanie geomorfologiczne otoczenia stanowisk archeologicznych Bytkowo 1 oraz Sobota 10, maszynopis w archiwum Pracowni Archeologiczno-Konserwatorskiej mgr Alina Jaszewska.

Pawlak P., Pietrzak R., Zisopulu-Bleja K. 2006, Osadnictwo wczesnośredniowieczne, późnośredniowieczne i nowożytne na stan. 1 w Gluchowie, w: Gluchowo, gm. Komorniki, stan. 1, A2-AUT145. Osadnictwo wielokulturowe, maszynopis w archiwum Fundacji Patrimonium.

Pawlak E., Pawlak P. 2018c, Osadnictwo wczesnośredniowieczne, w: A. Dębski, W. Kaczor, A. Kucharczyk, E. Pawlak, P. Pawlak, I. Sobkowiak-Tabaka, M. Włodarczak, M. Żółkiewski, Opracowanie wyników badań archeologicznych na stanowisku nr 29 w miejscowości Krąlewo, pow. poznański, woj. wielkopolskie, Poznań, maszynopis w archiwum Powiatowego Konserwatora Zabytków w Poznaniu, s. 477-655. 


\section{Źródła}

Thietmar - Kronika Thietmara, M.Z. Jedlicki (tłum.), 2005 Kraków, Towarzystwo Autorów i Wydawców Prac Naukowych Universitas.

\section{Publikacje}

Dąbrowski E. 1998, Wczesnośredniowieczny poznańsko-zaodrzański trakt tranzytowy w świetle badań archeologicznych w Pszczewie (1956-1960), w: H. Kóčka-Krenz, W. Łosiński (red.), Kraje stowiańskie w wiekach średnich. Profanum i sacrum, Stowarzyszenie Naukowe Archeologów Polskich, Oddział w Poznaniu, Poznańskie Towarzystwo Przyjaciół Nauk, s. 246-261.

Dzieduszycki W., Przybył M. 2002, „,Trakt cesarski” - próba odtworzenia przebiegu drogi pielgrzymki Ottona III do Gniezna na podstawie analizy źródeł pisanych i archeologicznych, w: W. Dzieduszycki, M. Przybył (red.), Trakt cesarski. Itawa, Gniezno, Magdeburg, Poznań, Poznań, Muzeum Archeologiczne w Poznaniu, s. 17-32.

Feldmanowski H. 1877, Wykopalisko pawłowickie, Poznań, Księgarnia J.K. Żupańskiego.

Góra M. 2004, Osada otwarta z okresu wplywów rzymskich $i$ wczesnośredniowieczna osada obronna w Barkowicach Mokrych koło Sulejowa, „Prace i Materiały Muzeum Archeologicznego i Etnograficznego w Łodzi", t. 42, s. 516-560.

Hensel W., Hilczer-Kurnatowska Z. 1980, Studia i Materiaty do osadnictwa Wielkopolski wczesnohistorycznej, t. 5, Wrocław-Warszawa-Kraków-Gdańsk, Zakład Narodowy Imienia Ossolińskich, Wydawnictwo Polskiej Akademii Nauk.

Kara M. 2009, Najstarsze państwo Piastów - rezultat przełomu czy kontynuacji? Studium archeologiczne, Poznań, Instytut Archeologii i Etnologii Polskiej Akademii Nauk.

- 2016, Relikty osadnictwa ze starszych faz wczesnego średniowiecza oraz przełomu faz starszych i młodszych od około VI/VII do pierwszej połowy XI w. z obszaru obecnej aglomeracji miasta Poznania. Próba zarysu przemian osadniczych wedlug nowszych ustaleń archeologii, w: M. Kara, M. Makohonienko, A. Michałowski (red.), Przemiany osadnictwa i środowiska przyrodniczego Poznania i okolic od schytku starożytności do lokacji miasta, Poznań, Bogucki Wydawnictwo Naukowe, s. 71-132.

Kočka-Krenz H. 2005, Najstarszy Poznań, w: Z. Kurnatowska, T. Jurek (red.), Civitas Posnaniensis. Studia z dziejów średniowiecznego Poznania, Poznań, Wydawnictwo Poznańskiego Towarzystwa Przyjaciół Nauk, s. 27-42.

Kowalewski J. 1997, Rola rowów we wczesnośredniowiecznych osadach z rejonu Pojezierza Chetmińsko-Dobrzyńskiego, „Archaeologia Historica Polona”, t. 6, s. 101-121.

Krzyszowski A. 2009, Osadnictwo pradziejowe i wczesnośredniowieczne w Niepruszewie (stan. 49), gm. Buk, w powiecie poznańskim, „Fontes Archaeologici Posnanienses”, t. 45, s. 165-226.

- 2018, Osada z VII-VIII wieku na stanowisku 15 w Wilanowie, gm. Kamieniec, pow. grodziski, w: J. Wierzbicki (red.), Badania archeologiczne na Nizinie Wielkopolsko-Kujawskiej w latach 2013-2017, Poznań, Instytut Archeologii Uniwersytetu im. Adama Mickiewicza, Muzeum Archeologiczne w Poznaniu, Instytut Archeologii i Etnologii PAN, Ośrodek Studiów Pradziejowych i Średniowiecznych, Wielkopolski Wojewódzki Konserwator Zabytków, Oddział Wielkopolski Stowarzyszenia Naukowego Archeologów Polskich, Poznańskie Towarzystwo Prehistoryczne, Poznań, s. 167-177.

Kurnatowska Z., Łosińska A. 1985, Sprawozdanie z weryfikacji grodzisk wielkopolskich w latach 1983-1984, Fontes Archaeologici Posnanienses, t. 34, s. 77-85.

Labuda G. 1988, Studia nad poczatkami państwa polskiego, t. 2, Poznań, Wydawnictwo Naukowe UAM.

Łosiński W. 2008, Pomorze Zachodnie we wczesnym średniowieczu. Studia archeologiczne, Poznań, Instytut Archeologii i Etnologii PAN.

Messal S. 2011, Zur slawischen Keramik des Typs „Glienke“, w: F. Biermann, T. Kersting, A. Klammt (red.), „Der Wandel um 1000. Beiträge zur Ur- und Frühgeschichte Mitteleuropas”, t. 60, s. 347-349.

Miśkiewicz B. 1991, Szkice z dziejów wojskowości, Warszawa-Poznań, Wydawnictwo Naukowe. 
Pawlak E. 2016, Wczesnośredniowieczna osada w Bytkowie pod Poznaniem, „Raporty”, t. 11, s. 123-165.

- 2018, Wielokulturowe stanowisko 39 w Kraplewie, gm. Stęszew, w: J. Wierzbicki (red.), Badania Archeologiczne na Nizinie Wielkopolsko-Kujawskiej w latach 2013-2017, Poznań, Instytut Archeologii Uniwersytetu im. Adama Mickiewicza, Muzeum Archeologiczne w Poznaniu, Instytut Archeologii i Etnologii PAN, Ośrodek Studiów Pradziejowych i Średniowiecznych, Wielkopolski Wojewódzki Konserwator Zabytków, Oddział Wielkopolski Stowarzyszenia Naukowego Archeologów Polskich, Poznańskie Towarzystwo Prehistoryczne, Poznań, s. 145-157.

Pawlak E., Pawlak P. 2018a, Najdawniejsze siedziby Slowian $w$ Wielkopolsce na podstawie wybranych źródet archeologicznych, w: M. Błażejewska, J. Wrzesiński, J. Goszczyńska, H. Machajewski, M. Świtoń (red.), Archeologia dawnego osadnictwa Wielkopolski, Poznań, Wojewódzki Konserwator Zabytków, s. 43-79.

- 2018b, Poznań, ul. Śródka 7 - badania wykopaliskowe w 2017 r., w: J. Wierzbicki (red.) Badania Archeologiczne na Nizinie Wielkopolsko-Kujawskiej w latach 2013-2017, Poznań, Instytut Archeologii Uniwersytetu im. Adama Mickiewicza, Muzeum Archeologiczne w Poznaniu, Instytut Archeologii i Etnologii PAN, Ośrodek Studiów Pradziejowych i Średniowiecznych, Wielkopolski Wojewódzki Konserwator Zabytków, Oddział Wielkopolski Stowarzyszenia Naukowego Archeologów Polskich, Poznańskie Towarzystwo Prehistoryczne, Poznań, s. 179-191.

- 2019a, Gród w Dąbrówce na tle sieci wczesnośredniowiecznych warowni z czasów przedpiastowskich na zachód od poznańskiego Przetomu Warty, w: M. Szmyt, P. Pawlak (red.) Dwa grody nad Wirynką. Dąbrówka, stanowiska 1 i 2, woj. wielkopolskie, Poznań, Muzeum Archeologiczne w Poznaniu, s. 659-675.

- 2019b, Charakterystyka ceramiki wczesnośredniowiecznej na stanowisku 2 w Dąbrówce, w: M. Szmyt, P. Pawlak (red.), Dwa grody nad Wirynką. Dabrówka, stanowiska 1 i 2, woj. wielkopolskie, Poznań, Muzeum Archeologiczne w Poznaniu, s. 659-675.

- 2019c, Najbliższe otoczenie osadnicze grodu na stanowisku 2 w Dąbrówce, w: M. Szmyt, P. Pawlak (red.), Dwa grody nad Wirynka. Dąbrówka, stanowiska 1 i 2, woj. wielkopolskie, Poznań, Muzeum Archeologiczne w Poznaniu, s. 173-324.

Pietrzak R. 2003, Wstępne wyniki badań grodzisk wczesnośredniowiecznych na Równinie Szamotulskiej, „Wielkopolskie Sprawozdania Archeologiczne”, t. 6, s. 52-75.

Przybył M. 2005, Poznań na tle szlaków komunikacyjnych od X do XIII wieku, w: Z. Kurnatowska, T. Jurek (red.), Civitas Posnaniensis. Studia z dziejów średniowiecznego miasta, Poznań, Wydawnictwo Poznańskiego Towarzystwa Przyjaciół Nauk, s. 111-129.

Stownik geograficzny Królestwa Polskiego i innych krajów słowiańskich, 1886, t. 7, B. Chlebowski, W. Walewski (red.), t. 7, Warszawa.

Surowiecki F. 1818, O rzekach y spławach kraiów Xięstwa Warszawszkiego, Warszawa, Drukarnia Rządowa.

Szałata A., Makohonienko M., Jasiewicz J. 2016, Analiza przestrzenna rozmieszczenia dawnego osadnictwa na obszarze miasta Poznania, w: M. Kara, M. Makohonienko, A. Michałowski (red.), Przemiany osadnictwa i środowiska przyrodniczego Poznania i okolic od schytku starożytności do lokacji miasta, Poznań, Bogucki Wydawnictwo Naukowe, s. 167-203.

Tabaka A., Zamelska-Monczak K. 2011, Wczesne średniowiecze, w: J. Kabaciński, I. Sobkowiak-Tabaka (red.), Materiaty do wczesnych pradziejów Wielkopolski. Osadnictwo pradziejowe i wczesnośredniowieczne w Lubrzy, Poznań, Instytut Archeologii i Etnologii PAN, s. 443-716.

Wędzki A. 1996, Na zachód od Poznania, w: Z. Kurnatowska (red.), Stowiańszczyzna w Europie średniowiecznej, t. 1, Wrocław, Instytut Archeologii i Etnologii PAN, s. 69-73.

Zamelska-Monczak K. 2008, Santok - , klucz i strażnica królestwa” u zbiegu warty i Noteci, w: J. Kolenda (red.), Milicz. Clavis Regni Poloniae. Gród na pograniczu, Wrocław, Instytut Archeologii i Etnologii PAN, s. 213-224.

Żak J., Maćkowiak-Kotkowska L. 1988, Studia nad uzbrojeniem środkowoeuropejskim VI-X wieku. Zachodniobaltyjskie $i$ stowiańskie ostrogi o zaczepach haczykowato zagiętych do wnętrza, Poznań, Wydawnictwo Naukowe Uniwersytetu Adama Mickiewicza w Poznaniu. 